\title{
TANULMÁNYOK
}

\author{
NÉMETH NÓRA - VIRÁG ZSOLT
}

\section{A KESZTHELYI FESTETICS-KASTÉLY ÉPÍTÉSTÖRTÉNETE AZ ÚJ KUTATÁSOK TÜKRÉBEN}

Magyarország egyik legnagyobb méretű kastélyépületével, a keszthelyi Festetics-kastéllyal a korábbiakban Péczely Piroska foglalkozott behatóan. Az 1950-es és 60-as években megjelent közleményei a közelmúltig a legteljesebb feldolgozását jelentették e fontos, több korszak kultúráját képviselő épületnek. ${ }^{1}$ Jelen tanulmányunkban az ő munkájára is támaszkodva, de új kutatások, a közelmúltban feltárt levéltári források, publikálatlan tervek és eddig ismeretlen archív fotók felhasználásával kívánjuk a kastély építéstörténetét összefoglalni, számos új elemmel gazdagítva azt. ${ }^{2}$

A mai kastély három fő periódusban épült: a keleti főszárny Festetics Kristóf idején 1745 és 1750 között, a déli oldalszárny és annak kiforduló szárnyrésze (könyvtárszárnya) Festetics (I.) György idején 1792 és 1804 között, majd az északi szárnyrészek Festetics (II.) Tasziló idején 1883 és 1887 között. Bár ezen kívül több ízben tervezték az épület átalakítását különböző időpontokban, ezen tervek nem valósultak meg, egy kisebb átalakítást kivéve, amelyre Festetics (I.) Tasziló birtokossága idején, 1866-ban került sor.

A kastélyt az évszázadok folyamán a Festetics család nyolc generációja lakta; a rezidencia építéstörténetét az egyes tulajdonosokhoz kapcsolódóan mutatjuk be. A kastély teljes épületén egységes szempontok szerinti, minden részletre kiterjedő falszövetkutatásra ez idáig nem nyílt lehetőség, csak egyes részek megvizsgálására. Egy esetleges későbbi épületkutatás tovább árnyalhatja majd a rezidencia építéstörténetét.

\section{1739-1768 - FESTETICS KRISTÓF (1696-1768) BIRTOKOSSÁGÁNAK IDEJE}

A keszthelyi uradalom megszerzése, a Festeticsek birtokosságát megelőzó épületek nyomai

Festetics (II.) Pál - aki pályája során főhadnagy, kapitány, dunántúli alkapitány és országgyülési követ volt - 1712. február 20-án vette zálogba gersei gróf Pethő János keszthelyi birtokait 5000 forintért. $^{3}$ Keszthely azonban kissé félreesett a többi birtokától, ezért 1719. szeptember 13-án elcserélte az itteni javak zálogjogát Bakó Farkassal annak nagybajomi birtokáért, s a kettő értékkülönbözeteként további 3124 forintot fizetett Bakónak. ${ }^{4}$ Ezt a cserét 1722. augusztus 6-án Pethő János is megerősítette. ${ }^{5}$

Festetics (II.) Pál fia, Festetics Kristóf 1738-ban visszaváltotta Bakó Farkastól a Pethő család ná- la zálogban lévő keszthelyi birtokait, ${ }^{6}$ majd 1739. február 6-án a település legnagyobb birtokosától, gersei gróf Pethő Zsigmondtól 24000 forintért megvásárolta a perekkel terhelt keszthelyi uradalmat. ${ }^{7}$ A pereket még ezután is tovább folytatta. Mária Terézia királynő 1741. augusztus 23-án kelt oklevelével megerősítette Festetics Kristófot és utódait Keszthely birtokában. ${ }^{8}$

A mai kastély pincéjében végzett részleges falszövetkutatás adatai szerint a pince falai magukban foglalják egy korábban itt állt épület megmaradt pincerészét. ${ }^{9}$ Ez a korábbi épület a Festeticsuradalom első, 1741-es összeírása alapján azzal a plébániatemplomtól nyugatra említett földszintes majorsági kőházzal azonosítható, ${ }^{10}$ amelyet a gersei 
gróf Pethő család nála zálogban lévő birtokán Bakó Farkas emeltetett a zálogbirtokosság időtartama alatt, valamikor 1719 és 1738 között. ${ }^{11}$ (A majorságot két jobbágytelekből alakították ki, 1699-ben még csak egy sövényfalú házat említettek ezen a területen. ${ }^{12}$ ) Az említett majorsági kőházból megmaradt kelet-nyugati hossztengelyü, kőből rakott boltozatú pincerész napjainkban a fó, délkeleti, legrégebbi kastélyszárny alatti pince déli traktusát képezi. Az ettől északra található pinceterek fal-, tám- és boltozati rendszere már a Festetics Kristóf által emelt első kastély földszinti térrendszerével megegyező elrendezésü, a falai a földszinti térrendszer falainak terheit hordják, tehát minden bizonnyal egyszerre épültek. Az, hogy a kőből rakott boltozatú pincetérhez a tőle északra lévő pincerész utólag épült hozzá, abból is látható, hogy az új pinceterek kiépítésekor a kőből épített korábbi boltozatot megbontották, s benne az új, szomszédos terek felé kapcsolódást teremtve téglából készült boltfiókokat építettek ki. ${ }^{13}$ Péczely Piroska is publikált egy megfigyelést, amely szerint a kastély ugyanezen részének 1966ban kezdődött felújításakor: „A munkálatok során a déli szárny keleti sarkánál levert vakolat alól óriási terméskövekből épült rendkívül vastag fal bontakozott ki." ${ }^{14}$

\section{Festetics Kristóf kastélya a tervek és a leírások alapján}

Festetics Kristóf pályája során Somogy vármegyei országgyülési követ, Somogy vármegyei alispán, a Helytartótanács tagja, aranysarkantyús vitéz, és a Hétszemélyes tábla bírája (septemvir) volt. 1746-ban az uralkodó neki és bátyjának, Józsefnek adományozta a Tolna vármegyei Tolna mezővárost, egyúttal a „tolnai” nemesi előnevet. Ô volt a család legjelentősebb vagyonszerzője, a keszthelyi hitbizomány megalapítója, és az ő nevéhez füződik a keszthelyi családi rezidencia felépítése is, amely épület a mai kastély délkeleti szárnyát képezi.

Festetics Kristóf 1745-ben kezdte meg a keszthelyi kastély felépítését, amelyről Móricz András 1745. április 14-én Pozsonyból Ságra - a Festeticsek másik jelentős birtokközpontjába - küldött levele tanúskodik, amely „Keszthely Ipületnek, melyet az Ingineur kezembe adót, Delineatioját [tervét, rajzát]” említette. ${ }^{15}$ Sajnos az említett „Ingineur", azaz mérnök (építőmester) kilétéről nincs pontosabb információ. A kastély munkálatai 1750-ben fejeződhettek be, ugyanis egyazon év január 27-ei forrás már arról számolt be, hogy Simon Eder asz- talos legénye két hétig padlót rakott a „fölső házakban", valamint Szaurer István tiszttartó számadáskönyve szerint szintén ebben az évben az „Uy épületben" az ajtókat is lefestették. ${ }^{16}$

A földbirtokos által barokk stílusban emeltetett egyemeletes kastély megközelítően téglalap alaprajzú volt. Az építés időszakából tervrajzot nem ismerünk az épületről, ekkori alaprajza, kialakítása azonban későbbi források alapján jól rekonstruálható. A meg nem valósult 1755 -ös, ${ }^{17} 1759$-es, ${ }^{18}$ 1768 -as, ${ }^{19} 1769-$ es $^{20}$ és 1770 -es ${ }^{21}$ keltezésű bővítési terveken látható a meglévő épület alaprajza is, de az 1783-as I. katonai felmérés térképén lévő épületkontúr is még mindig csak a Festetics Kristóf által emelt kastély kialakítását rögzítette. Különösen az 1769-es átépítési terv árul el sokat a kastély ezen első építési periódusáról, mivel a meglévő részeket fekete színnel, az újonnan építendő részeket pedig rózsaszínnel jelölte mind a földszinten, mind az emeleten.

Az említett források alapján megállapítható, hogy a keszthelyi kastély ekkori formájában egy tehetős, a köznemesség vagyonos felső rétegéhez tartozó földbirtokos barokk kastélyának a tipikus kialakítását követte, sőt, az utóbb jelentősen kibővített rezidencia e délkeleti szárnyának a tömege és térstruktúrája lényegét tekintve ma is a Festetics Kristóf által felépített formájában látható. A középrizalit földszintjén kocsiáthajtós kapualj, az emeleten pedig díszterem (nagyebédlö) létesült, az északi és a déli szárnyrészek mindkét szinten kéttraktusos elrendezést kaptak, traktusonként 3-3 helyiséggel. Természetesen a kastély pincéjének e része is elnyerte - föbb jellemzőit tekintve - mai formáját már az első építési periódusban, amint az egy későbbi, 1799-es keltezésü, Rantz János György által készített kastélybővítési terv metszetén is látható. 22

Bél Mátyás latin nyelvű leírásában így írt a városról és a kastélyról: „Az intenzív szőlőművivelésen és a korszerű földművelésen kívül híresek a vásárai. Egykor a Pethő család örökös birtoka, most Festetich Kristóf családjának engedelmeskedik és a kellemes fekvésű kastéllyal, s más fényűző épületek és kertek gyönyörüségével, a tengerihez teljesen hasonlatos, kellemes hajókázással, vadászattal és halászattal a Festetichek hozzáértése által úgy el van látva, hogy igen sok néző lelkét képes megragadni és felvidámítani. ${ }^{23} \mathrm{~A}$ kor jellegzetes fogalmazási módját tükröző leírás a kastély 1745-ben megkezdett felépítése és Bél 1749 augusztusában bekövetkezett halála közötti időszakban keletkezhetett, feltehetően akkor, amikor kívülről már készen állt az épület. 
A fennmaradt tervlap tanúsága szerint a folyamatosan gyarapodó vagyonú Festetics Kristóf egy évtizeddel később, 1755-ben már U alakú, két hátranyúló szárnnyal rendelkező rezidenciává szerette volna kibővíteni keszthelyi kastélyát, ${ }^{24}$ ez a terv azonban nem valósult meg (1. kép).

A tervet Hoffstedter Kristóf (1717-1782), eredeti névírással Christoff Carl von Hoffstedter (más formában Hofstädter, Hofstaedter), az uradalom „első kőmíves mestere” - vagy ahogyan a tervaláírásokon németül szerepelt: „mauermeister” - látta el aláírásával. (Az, hogy az építőmester írta alá a tervet, a kor uradalmi építési irodáinak müködési gyakorlatát ismerve nem jelentette azt feltétlenül, hogy azt személyesen ő is rajzolta, viszont a terv kidolgozásában bizonyosan döntő részt vállalt.) Arra vonatkozóan ez idáig nem került elő adat, hogy az 1745-ben megkezdett Festetics Kristóf-féle kastélyt Hoffstedter Kristóf tervezte volna, viszont befejező munkálatainál már biztosan szerepet játszott. Neve és pecsétje először a Festetics-kastély 1749. évi építkezési elszámolásán a kőművesek, napszámosok és ácsok bérjegyzékének aláírásában szerepelt. ${ }^{25}$
Hoffstedter Lotaringiából származott, Keszthelyen akkor telepedett le, amikor a birtok megszerzése után Festetics Kristóf német nyelvterületről mesterembereket hívott a városba; Hoffstedtert már valószínűleg Bécsből szerződtették az itteni feladatokra. A kiváló szervezőként ismert mester irányította haláláig a Festetics-uradalom építési irodáját is. Keszthelyen az ő vezetésével alapították meg 1751-ben a kőmüvesek, kőfaragók és ácsok céhét. $^{26}$

1759-ből újabb Hoffstedter-terv maradt fenn a levéltárban a kastély kibővítésére vonatkozóan, ${ }^{27}$ azonban ez sem került megvalósításra. A tervlapon a rezidencia földszinti alaprajza, a közeli melléképületek földszinti alaprajza, és a park látható. Az 1755-ös tervhez képest csekély változtatást tartalmazó rajzokon jelölték a boltozatokat is, és egy nyitott kocsiáthajtó formájában megjelent az átjárás elvi lehetősége a tervezett északi szárny közepén a kastélyudvarból a melléképületek felé. Ez az első fennmaradt terv a melléképületekre vonatkozóan, a feliratok tanúsága szerint istállót, szénatárolót, fészert, kovácsműhelyt, és az istállótisztek szobáit tervezték bennük elhelyezni (2. kép).

\section{1768-1782 - GRÓF FESTETICS (III.) PÁL (1722-1782) BIRTOKOSSÁGÁNAK IDEJE}

Festetics Kristóf idősebb fia, Festetics (III.) Pál fényes pályát futott be. Ennek során 1748-tól Sopron vármegye helyettes alispánja, 1749-56-ban alispánja, 1751-ben országgyűlési követe, 1756-ban a kőszegi kerületi tábla ülnöke, 1758-tól udvari tanácsos, 1759-től kamarai tanácsos, az 1767-es úrbérrendezés legfőbb kidolgozója, 1772-től a magyar kamara alelnöke, 1777-től pedig Baranya vármegye főispánja volt. A földbirtokosnak 1772-ben magyar grófi rangot adományozott Mária Terézia királynő, ily módon a Festetics család a főnemesség soraiba emelkedett.

\section{Tervváltozatok 1768 és 1770 között}

(III.) Pál a birtok 1768-as megöröklése után, még azon év júniusában új tervváltozatot készíttetett Hoffstedter Kristóffal a rezidencia bővítésére. ${ }^{28}$ Ezt követően Hoffstedter 1769-es ${ }^{29}$ és 1770-es keltezésű terveket, tervváltozatokat ${ }^{30}$ is készített a kastély átalakítására. Mind követte az eddigi változatokat abban, hogy a kastély U alakú lett volna, ha megvalósul valamelyikük. Mivel azonban Festetics pénzügyi helyzete folyamatosan romlott, az építkezések megvalósításához szükséges anyagi háttér soha nem állt a rendelkezésére, ily módon egyik átépítési terv sem valósult meg.

Hoffstedter Kristóf az előbb említett 1768-ban készített tervrajza az 1759-essel minden lényeges elemében megegyezik. A kastély épületét tekintve apróbb változás, hogy a délkeleti sarokhoz csatlakozó kertfal nyugatabbra került, valamint egy kályha elhelyezése módosult a déli szárnyban. Jelentősebb különbség hogy a korábbi, 1755-ös és tulajdonképpen a most tárgyalt 1759-es terv zárt megoldásával szemben is a hátranyúló szárnyak udvari oldalának a földszinti középső része nyitott, árkádos kialakítást kapott volna az 1768-as terv szerint. Ez a nyitott megoldás jelenik meg innentől kezdve a későbbi, 1769-es és 1770-es terveken is (3. kép).

Az 1769-ben készült tervlapon az 1768-as tervlaphoz képest már markáns változásokat tapasztalunk: az U alakú kastély hátranyúló szárnyainak a végéhez már $L$ alakban kiforduló új szárnyrészeket is tervezett Hoffstedter, ily módon az ezen a terven látható alaprajz már talpas U betüt formáz. A kastély hátranyúló szárnyai egyemeletes, a kiforduló új szárnyrészek kétemeletes kialakításúak lettek volna. Ezen terv alapján látható, hogy a könyvtárterem kialakításának és épületen belüli elhelyezé- 


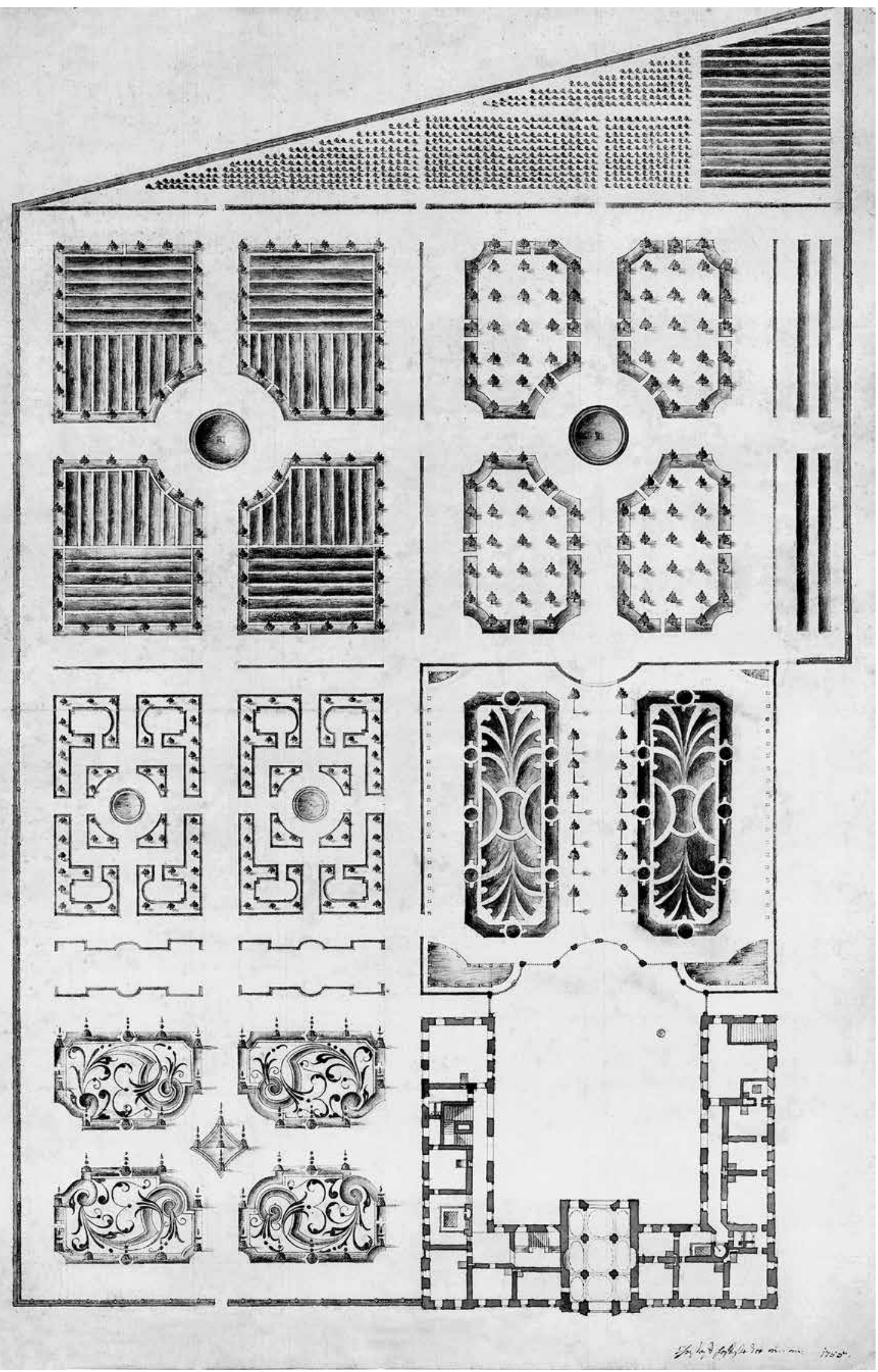

1. Hoffstedter Kristóf kőmíves mester első fennmaradt terve a kastélyról (földszint) és kertjéröl, 1755. MNL OL T 3 - No. 4. 


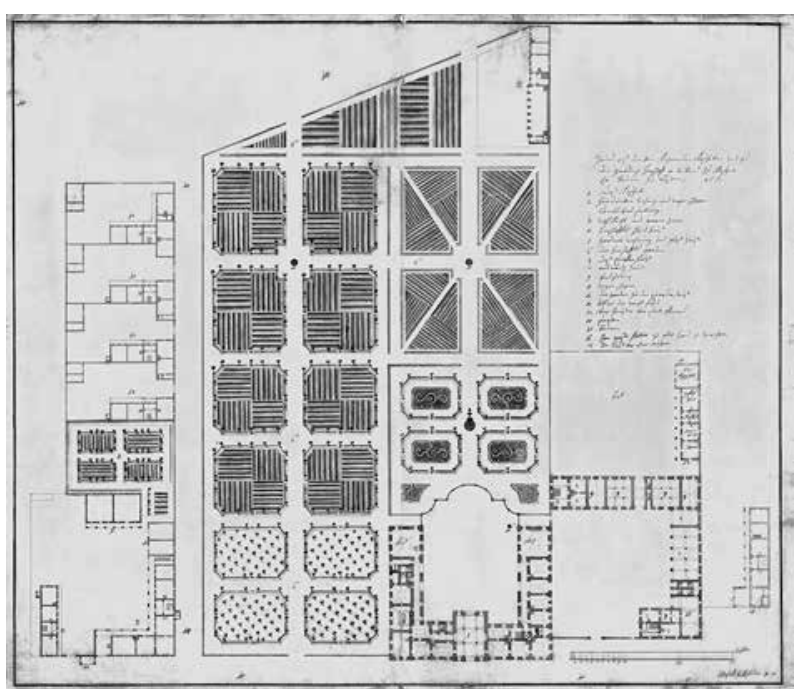

2. Hoffstedter Kristóf terve a kastélyról (földszint), melléképületeiről és kertjéről, 1759. MNL OL T 3 - No. 5.

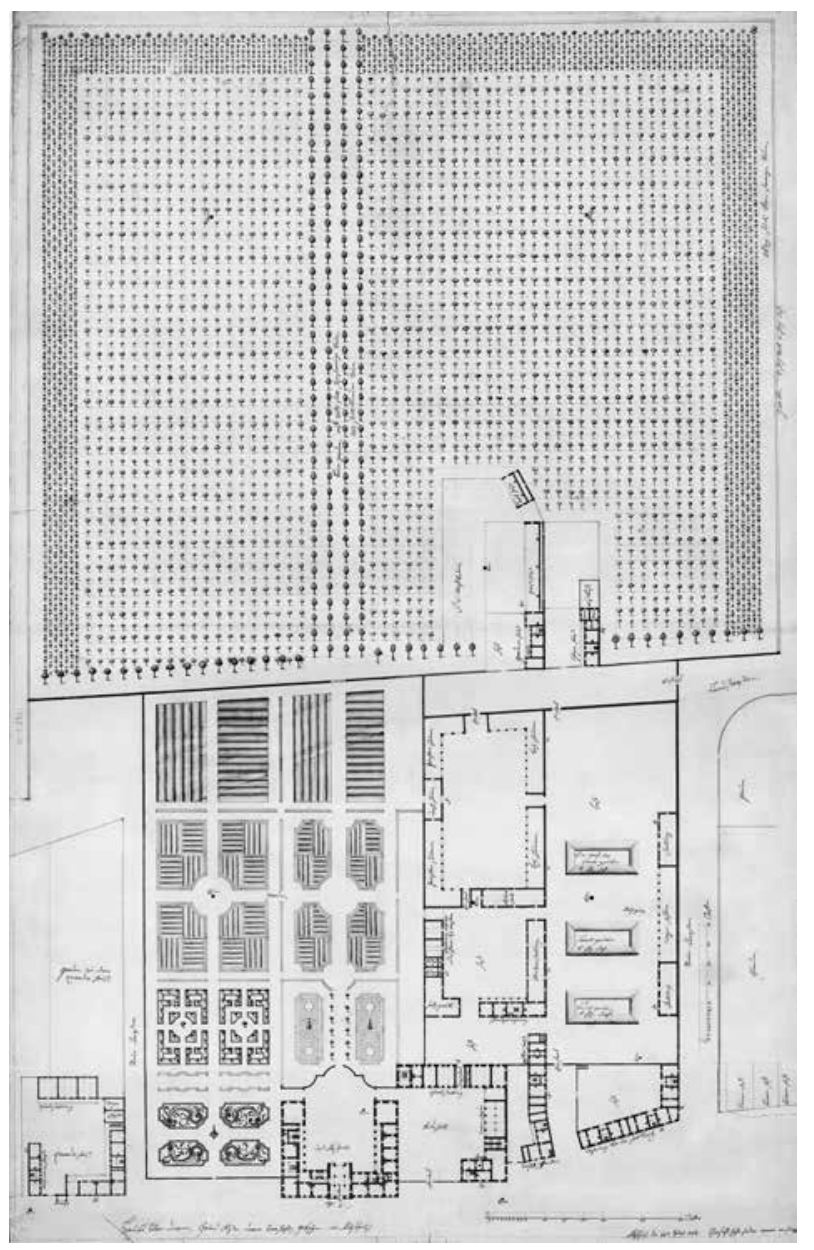

3. Hoffstedter Kristóf terve a kastélyról (földszint), melléképületeiről és kertjéről, 1768. MNL OL T 3 - No. 20.

sének a később, Festetics (I.) György birtokossága idején megvalósult gondolata már Festetics (III.) Pálnál felmerült.
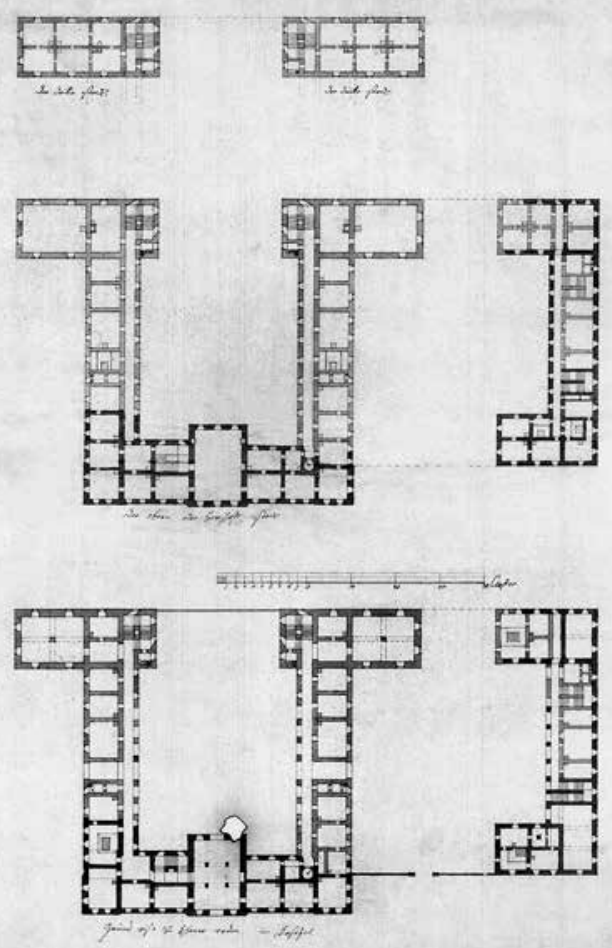

4. Hoffstedter Kristóf terve a kastély és a kiskastély átépitéséról (földszint, elsö emelet, második emelet) a meglévö és az új részek jelölésével, 1769. MNL OL T 3-No. 31.

Ahogyan már említettük, az 1769-es átépítési terv sokat elárul a bővíteni tervezett Festetics Kristóf-féle - megközelítően téglalap alaprajzú - barokk kastély, a mai épület legrégebbi része kialakításáról is, hiszen a terveken a meglévő részeket fekete színnel, az építendő részeket pedig rózsaszínnel jelölték, ez alapján is tudjuk, hogy a hátranyúló szárnyak kiépítését ekkor még csak tervezték. Mivel a rezidenciától északra fekvő egyemeletes kiskastély épülete is látható a terven, annak fekete jelölésü falai alapján tudjuk, hogy 1769-ben már ez az épület is állt teljes kiterjedésében, csak néhány módosítást eszközöltek volna rajta. Az 1768-as terv még a kiskastély nyugati szárnyának a jelentősebb kiépítésével számolt, ez azonban a kastély északi szárnyának az akkor megjelenő kiforduló új szárnya miatt az 1769-es tervről már elmaradt, mivel nem fért volna el (4. kép).

Érdekesség, hogy 1769-ből fennmaradt Keszthely mezőváros egy olyan térképe, amelyre már rárajzolták az 1769-es terven szereplő - de ebben a formájában soha meg nem valósult - kibővített kastélyt, valamint annak tervezett melléképületeit ${ }^{31}$ (5. kép).

A rezidencia homlokzatáról is ebből az évből, 1769-ből származik az első ismert terv. ${ }^{32}$ 


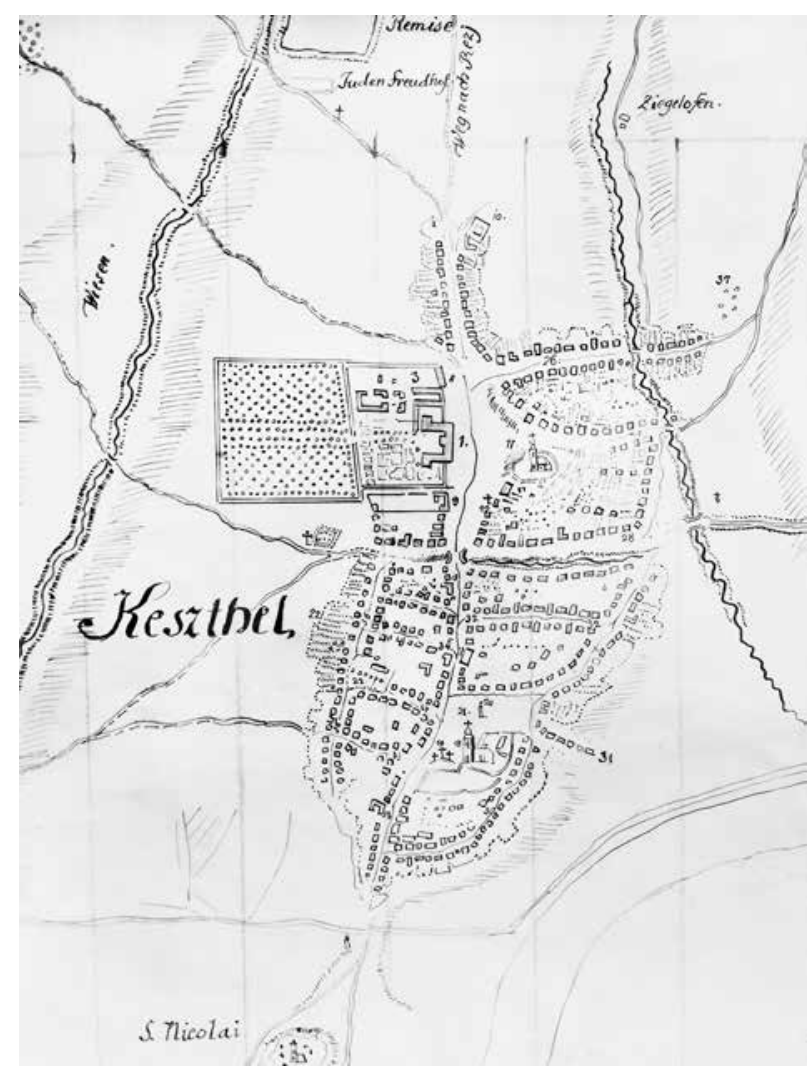

5. A keszthelyi uradalom helyszínrajza, amelyre rákerült a kibövíteni tervezett kastély új alaprajzi kontúrja is [Situation der Herrschaft Keszthel in Szaladienser Comitat], 1769. Balatoni Múzeum Térképtára, ltsz.: 75.525.

A Hoffstedter Kristóf által készített rajz nyugatról ábrázolja a kastélyt, amelyet - német nyelvű felirata szerint - a méltóságos úr építtetni szándékozik. ${ }^{33} \mathrm{Ez}$ a tervrajz komoly jelentőséggel bír, ugyanis negyed évszázaddal később tulajdonképpen ennek a logikája alapján, ehhez hasonló módon valósult meg a kastély részleges kibővítése - a déli oldal hátranyúló szárnyának a felépítése -, és az ezen ábrázolt kialakításhoz hasonló állapot látható a kastély nyugati (udvari) oldalának déli részéről fennmaradt, 1880 előtt készült fényképen. ${ }^{34}$ (Ez a Boros Imre keszthelyi fényképész által készített fotó azon két komoly forrásértékű archív kép egyike, amelyeken az 18831887-es nagy átalakítás és kibővítés előtti állapotában látható a keszthelyi rezidencia.) Szintén ezt a kialakítást örökítette meg Victor Rumpelmayer egyik datálatlan, de biztosan 1883-ban készült - még a régi állapotot rögzítő - nyugati homlokzati terve. ${ }^{35}$ Az 1769-es homlokzatterven a kastély keretelt ablakai egyszerű kialakításúak, a középrizalit félköríves emeleti és ovális földszinti ablakai kivételével egyenes záródásúak, az első emeleti ablakok felett egyenes szemöldökpárkány is látható. A földszint sávozott, a kétemeletes kiforduló szárnyak nyugati homlokzatának emeleti ablakait két szintet átfogó kettős pilaszterek tagolják. Az egyemeletes középrizalitot és a kétemeletes kiforduló szárnyakat manzárdtető borítja (utóbbi végül nem kapott manzárdos kialakítást). A kastélypark kerítését is feltüntették a homlokzatterven (6. kép).

Az 1770-es terv az 1769-es terv továbbfejlesztése kisebb módosításokkal. Hoffstedter Kristóf tehát több, lényegében csak részleteiben különböző barokk kastélybővítési tervet készített (7. kép).

Több olyan tervváltozat és helyszínrajz is fennmaradt a levéltárban, amelyeken nem szerepel dátum, ${ }^{36}$ ezek feltehetően 1755 és a kastély 1792-ben megkezdett bővítése közötti időszakban keletkeztek, és az 1755 és 1770 között készült tervek megoldásait ismétlik; van közöttük, amelyik még az 1755-68-as alaprajzot, és van, amelyik az 1769-70es alaprajzot mutatja.

\section{Festetics (III.) Pál kastélya a leírások és az inventáriumok alapján}

1770-ben Keszthelyen járt II. József német-római császár (1780-tól magyar király), akinek a kastély

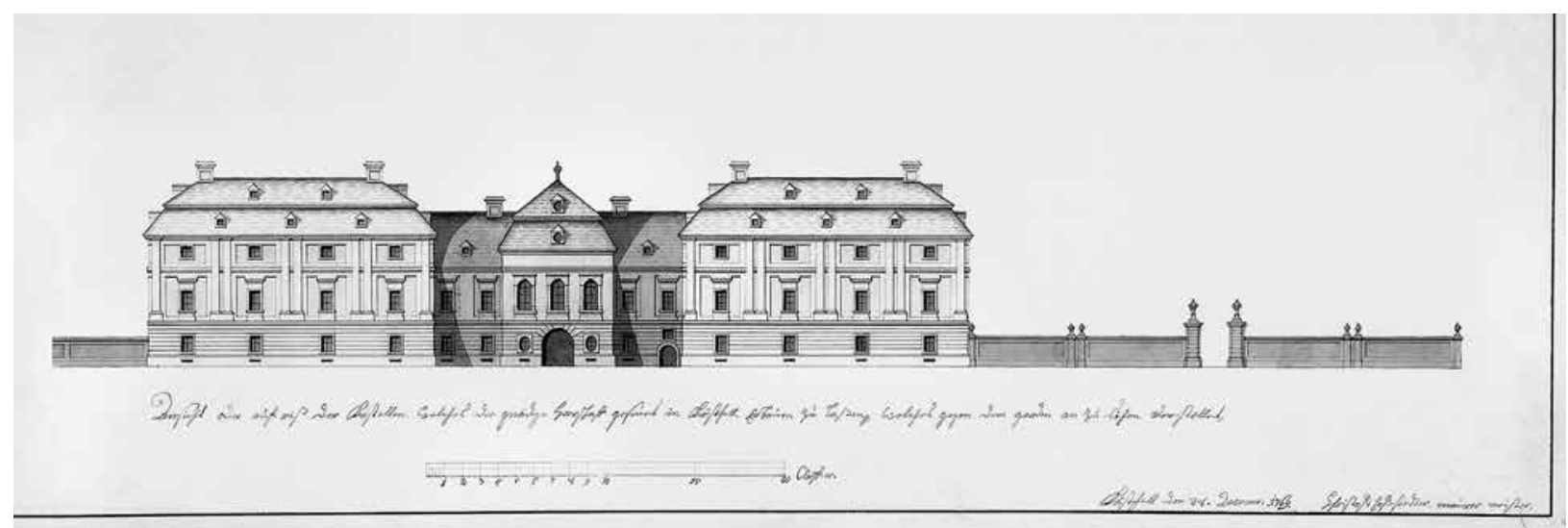

6. Hoffstedter Kristóf terve a kastély kibővitéséhez, nyugati homlokzat, 1769. MNL OL T 3-No. 32. 


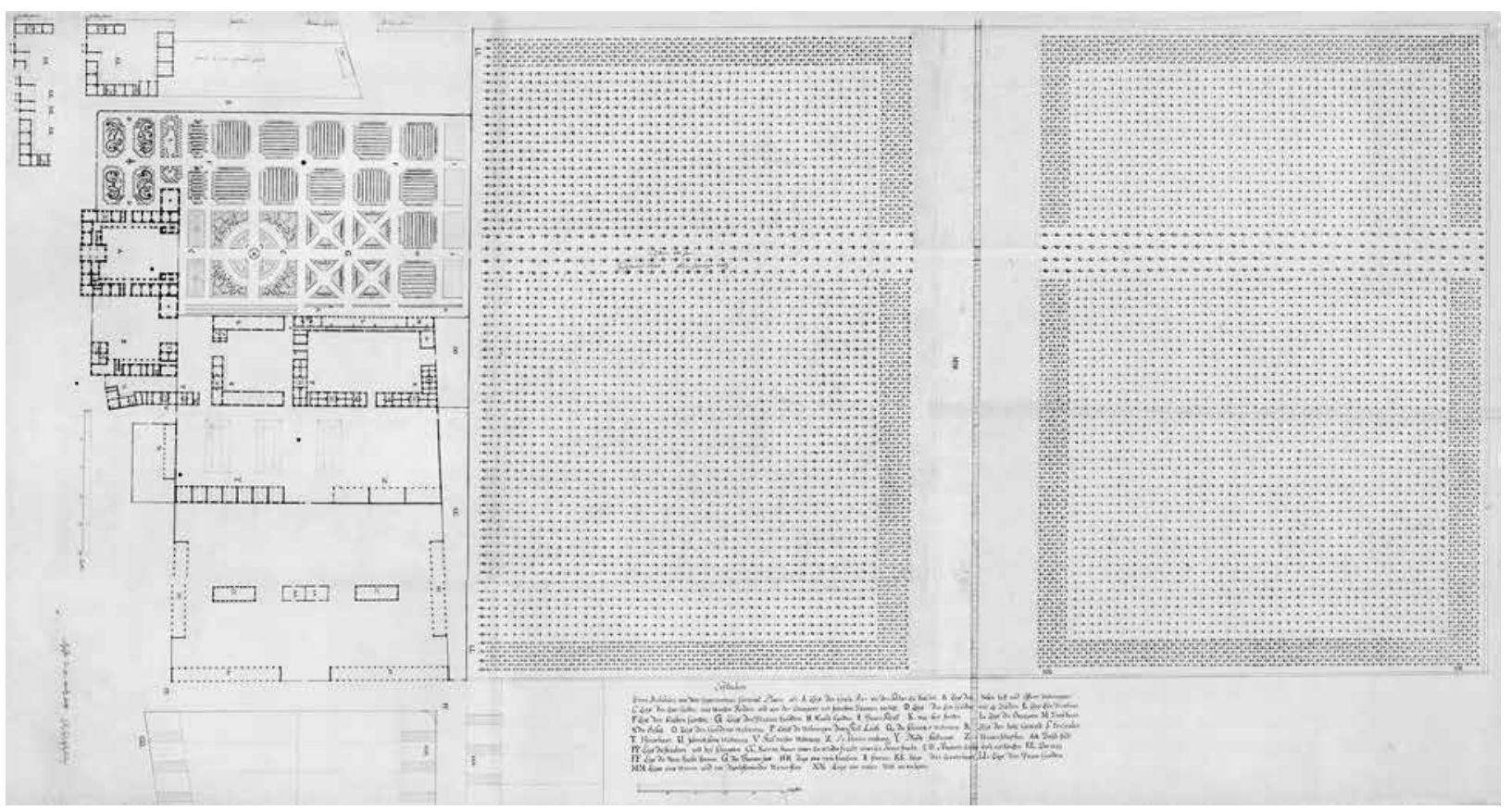

7. Hoffstedter Kristóf terve a kastélyról (földszint), melléképületeiröl és kertjéról, 1770. MNL OL T 3 - No. 40.

és a park elhelyezéséről alkotott véleményét a tiszttartó írta meg az éppen távol lévő Festetics (III.) Pálnak: „A fölséges császár... mondotta: Ha Festetics volnék, kastélyomat úgy építettem volna, hogy kertem a Balatonra leszolgált volna. Melyre én feleltem, hogy az épületet Méltóságos Urék Atyja kezdette." ${ }^{37}$ Valóban hosszú időn keresztül komoly problémát jelentett, hogy a kastély keleti főhomlokzata a város forgalmas főutcájára - egyben országútra - nézett, így hely hiányában az U alakúvá kiépíteni tervezett, majd a déli szárny tekintetében ténylegesen megvalósult bővítéssel az épület díszudvara nyugati irányba, a kert felé, nem pedig a keletre fekvő Balaton felé fordult. A díszudvarnak a kert felé történő kialakítása az európai gyakorlatban kevésbé volt megszokott, Magyarországon azonban - föként az ún. Grassalkovich-típusú kastélyoknál jellemző volt.

Apja halála után (III.) Pál az elkészült tervek alapján tehát már főnemesi rezidenciának készült kibővíteni a kastélyt, de ahogy erről már szó esett, anyagi erőforrások híján ekkor sem kezdődtek meg a munkálatok. Viszont lehetséges, hogy sor került egy kisebb léptékű aszimmetrikus bővítésre, ugyanis három 1790 körül keletkezett különböző - de könnyen lehetséges, hogy egymásról másolt - térképen és helyszínrajzon ${ }^{38}$ is megjelent a megközelítően téglalap alaprajzú, a kastély nyugati oldalának északi oldalrizalitjához merőlegesen kapcsolódó, a középrizalit (dél) felé benyúló rövid szárnyrész. Ennek a fóépülethez meglehető- sen szervetlenül kapcsolódó, szokatlan kialakítású szárnyrésznek az egykori létét azonban csak a mai kert területén végzett régészeti feltárással lehetne igazolni vagy cáfolni. (Amennyiben létezett ez a szárnyrész, akkor is igen rövid ideig állhatott fenn. Az 1791-92 körül készült terven ${ }^{39}$ - amely alapján végül a déli hátranyúló oldalszárny felépült, és amelyen a meglévő falakat fekete színnel jelölték ezen rövid északi szárnyrész létezésének nem találjuk nyomát.) (8. kép)

A nagyarányú építkezések elmaradása mellett azonban (III.) Pál 1772-ben kapott grófi rangjához illően felújíttatta a kastély berendezését. Pozsonyban bútorokat vásárolt, Bécsben képkereteket rendelt, majd 1780-ban Hubert Maurer cs. és kir. akadémiai festővel megfesttette saját és felesége portréját, de Antoine Rosier pozsonyi és Franz Wösner bécsi művészektől is vett festményeket. A gróf több díszes ezüst és arany edényt rendelt Joseph Stadlertől és Christoph Jungertől. A rezidenciában egy igen gazdag, 117 darabból álló rézmetszet-gyüiteményt őriztek. ${ }^{40}$ Megjelentek a kastélyban a technikai újdonságok is: „electrum, kamera obscura, szócső, barométer, thermometer, perspektiva", valamint a sakk mellett a trik-trak (ostábla) játék. ${ }^{41}$

Amikor Festetics (III.) Pál 1782 áprilisában elhunyt, hatalmas, 1150000 forintnyi adósság terhelte birtokait. ${ }^{42}$ Halálát követően, 1782 októberének végén egy német nyelvü leltár készült az épület berendezési tárgyairól, az inventáriumban a kastély és a kiskastély (,"HinterGebau") 29, illetve 11 helyisége szerepelt. ${ }^{43}$ 


\section{1782-1819 - GRÓF FESTETICS (I.) GYÖRGY (1755-1819) BIRTOKOSSÁGÁNAK IDEJE}

Festetics (III.) Páltól idősebb fia, Festetics (I.) György örökölte a keszthelyi birtokot. A gróf katonatisztként szolgált, alezredes volt a Graevenhuszárezredben, a katonai pályától 1791 májusában főként politikai okok miatt vonult vissza. Amikor hazatért Keszthelyre - zilált állapotban átvett birtokait mintegy egy évtizedig katonai állomáshelyeiről igazgatta -, a Festetics Kristóf által emelt barokk kastély volt az otthona.

\section{A kastély második jelentôs épitési periódusa: a déli oldalszárny}

Végül Festetics (I.) György volt az, aki a kastély korábban sokszor tervezett kibővítését megvalósította, igaz, ő is csak félig, ugyanis a tervezett két - a fóépülettel U alakot formázó - hátranyúló szárny közül csak a déli épült fel. A munkálatok anyagi hátterét a Festetics-uradalmak növekvő jövedelemtermelő képessége biztosította, köszönhetően a - Georgikont is megalapító - gróf által bevezetett rendkívül korszerü gazdálkodási formáknak.

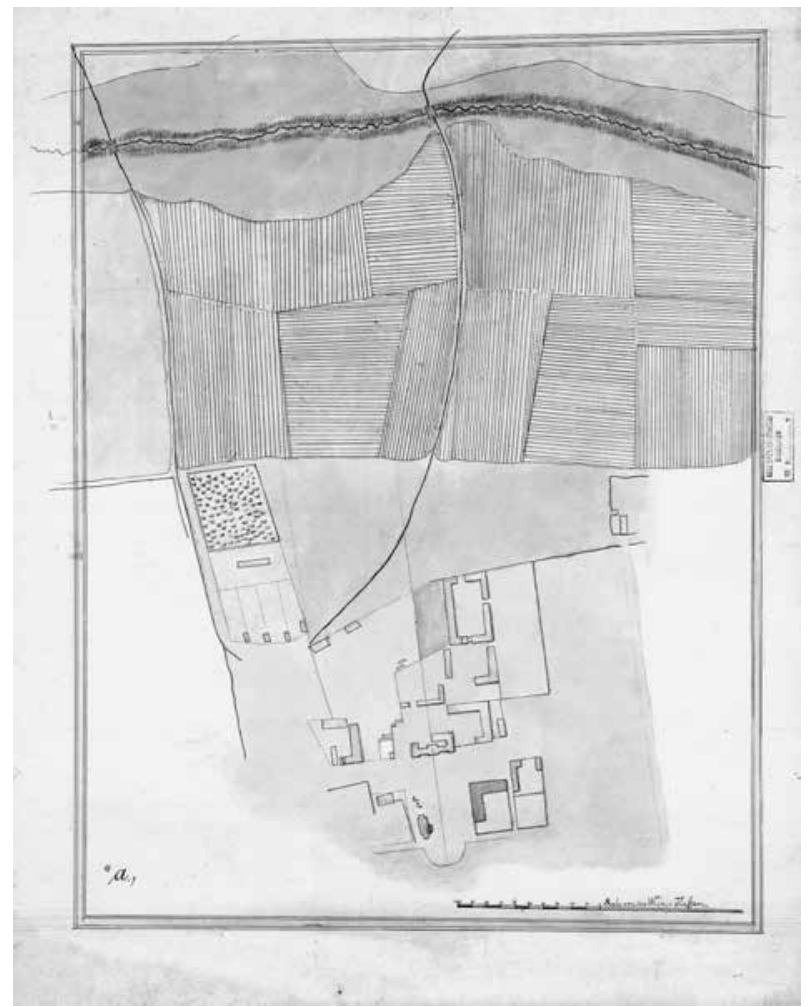

8. Rajz a kastélyról és környékéröl, feltehetően 1755 és 1792 között. OSzK TK 520
A kastély részleges kibővítése egy olyan tervlap alapján történt, ${ }^{44}$ amely datálatlan és szignálatlan formában a Magyar Nemzeti Levéltár anyagában található, ${ }^{45}$ egy utólag tévesen 1812-es évszámmal ellátott változatát ${ }^{46}$ pedig a keszthelyi Festetics-kastély Helikon Könyvtárában őrzik. A tervlap 1791-92 táján, közvetlenül az építkezések 1792-es megkezdése előtt, vagy valamivel korábban készülhetett. ${ }^{47}$ Ezen a földszinti részt ábrázoló terven szürkével jelölték a meglévő épületet - amely csak minimálisan, néhány közfalat tekintve tért el az 1769-es terven rögzített, akkor meglévő állapottól -, és rózsaszínnel tüntették fel a tervezett bővítést. Ezen terv alapján is megállapítható, hogy - a szakirodalom egy részében leírtakkal ellentétben - a terv készítésének időpontjában még nem voltak oldalszárnyai az épületnek (9. kép).

A részlegesen megvalósult 1791-92 körüli terv készítőjének a neve nem ismert. Hoffstedter Kristóf 1782-ben bekövetkezett halála után Sebestyén Sámuel mérnök vette át az uradalmi építési iroda vezetését, ${ }^{48}$ Rantz János György (eredeti névírással Johann Georg Rantz) kőmíves mester pedig a beosztottjaként működött, Rantz 1804-ben bekövetkezett haláláig. ${ }^{49}$

$\mathrm{Az}$ 1791-92 táján készült terv maradéktalan megvalósulása egy U alaprajzú, a szárnyvégeket összekötő félköríves alaprajzú kettős oszlop- vagy pillérsorral lezárt elegáns kastélyt eredményezett volna, azonban végül csak a déli szárny épült fel, az északi szárny és a kolonnád sosem készült el. Erre a legfontosabb bizonyíték az 1812-es hiteles kastélyalaprajz, ${ }^{50}$ felirata szerint „a keszthelyi kastély alaprajza 1812-es jelenlegi állapotában" - amelyen pontosan látható a felépült déli szárny, és annak valamennyi pinceszinti és földszinti helyisége -, valamint az 1858-as kataszteri térképen ${ }^{51}$ látható kastélykontúr.

Az 1791-92 táján készült bővítési terv és az akkor fennálló állapotot hitelesen bemutató 1812es felmérés között - a megépült déli épületrészek tekintetében - csak annyi a különbség, hogy egy tervezett közfal nem épült meg a déli szárny földszintjén a kiforduló szárnyrész (a könyvtárszárny) előtti utolsó szobában, egy közfalat viszont behúztak a kiforduló szárnyrész északnyugati traktusának középső termébe. A bővítési tervet elemezve az is megállapítható, hogy logikáját tekintve a Hoffstedter-féle 1769-es és 1770-es tervet követi a főszárnyhoz kapcsolódó egyemeletes oldalszárny hossza, valamint a kétemeletes kiforduló szárny- 


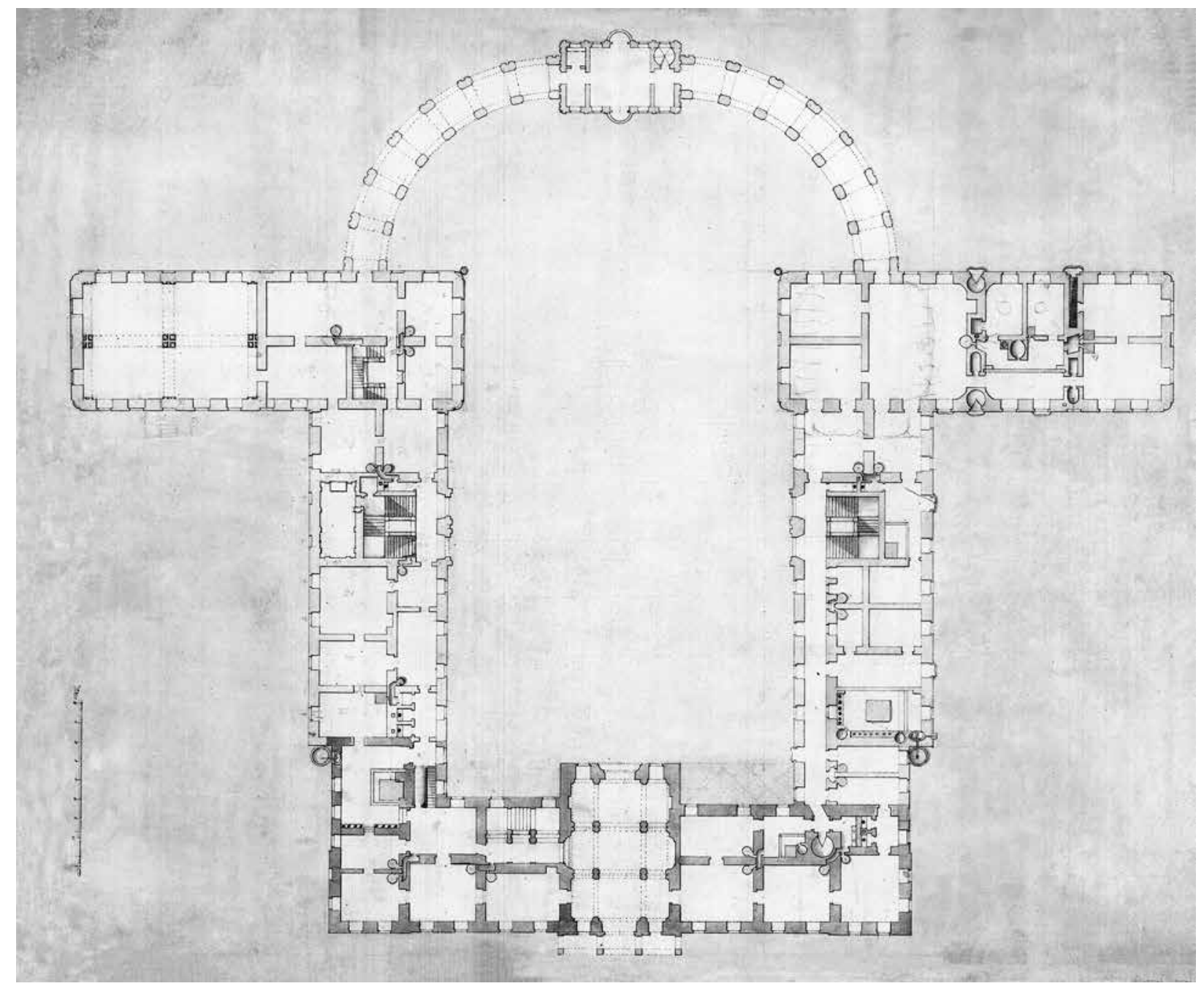

9. A kastély részben, a déli oldalszárny és kiforduló nyugati szárnyrésze (a könyvtárszárny) tekintetében megvalósult bővitési terve, földszint, 1791-92 körül. MNL OL T 3 - No. 334.

rész tekintetében is. Ugyanakkor az újonnan emelt oldalszárny végül az új terv alapján szélesebb lett a korábban tervezett szárnyrésznél, a kastély déli homlokzatán a régi és az új rész kapcsolódási pontjánál ma is jól látszik a kiugrás. A korábban tervezettnél szélesebb új szárny kialakítását az egy szobasoros udvari oldalfolyosós koncepció két szobasorosra módosulása indokolta, amely a földszint és az emelet térszervezésében is megjelent; a földszinten a korábban tervezett udvari oldali árkádos folyosók is szobasorrá bővültek, és ablakokat kaptak. A kiforduló szárnyrész (a könyvtárszárny) esetében annyi változás történt, hogy a korábban tervezettnél hosszabb lett déli irányban, viszont nem épült meg az északi (udvar felőli) kiugró része (rizalitja).

Ha az 1769-es Hoffstedter-féle nyugati (udvari) homlokzati rajzot és az 1880 előtt készült nyugati homlokzati fényképet, valamint Victor Rumpelmayer egyik datálatlan, de biztosan 1883ban készült - még a régi állapotot megörökítő - nyugati homlokzati tervét ${ }^{52}$ összevetjük, akkor látható, hogy az 1792-ben megkezdett Festetics (I.) György-féle klasszicizáló késő barokk átépítés során nemcsak az alaprajzok, hanem a homlokzatok tekintetében is a korábban tervezetthez hasonló koncepció valósult meg, csak klasszicizálóbb formában. Rumpelmayer terve és a fénykép ugyanazt az állapotot mutatja, így a 19. század végi átépítése előtt a középrizaliton félköríves záródású kapu nyílt, mellette két oldalt egy-egy ovális ablakot helyeztek el. Az 1769-es homlokzati terven a főszárny nyugati homlokzatának déli szakaszán megfigyelhetố a pincébe levezető - a falszövetkutatás során is azonosított - lépcső félköríves záródású kapuja, amely a fényképen és Rumpelmayer tervén már nem látható. A középrizalit emeleti ablakai is az 1769-es homlokzati tervhez hasonló formában láthatók az archív fotón, csak más kereteléssel. Az oromzat klasszicizálóbb kialakítású lett, timpanonos lezárást kapott. A nyugati homlokzat északi 
(bal oldali) háromtengelyes oldalrizalitjának a kialakítása is jól látható a Rumpelmayer-féle felmérési terven, és szintén innen ismerjük a déli szárny kiforduló szárnyrészének, a könyvtárszárnynak a klasszicizáló késő barokk jegyeket hordozó, kétemeletes, tizenegy tengelyes, rizalitokkal nem tagolt, hálózatos rendszerü nyugati homlokzatát, amelynek emeleti ablakait két szintet átfogó pilaszterek osztották, az első emeleti ablakok felett háromszög-szemöldökök sora húzódott, a földszinti ablakok pedig félköríves keretelést kaptak.

\section{Az épitkezés folyamata a források tükrében}

Az új déli kastélyszárny felépítésének a menetével kapcsolatban több adat maradt fenn a Festetics-levéltárban, többek között a Directoratus iratanyaga $^{53}$ között. Ezekből idézünk néhány fontosabbat. A kastély építési munkálatai 1792-ben már biztosan zajlottak, ugyanis 1792. június 4-én a tiszttartó azt írta, hogy „[a] kastély építése pedig hat-hét kőmüves legények munkálkodása mellett az elkezdett két szélső és az közép falak egyenlő magasságra föl lépett, és most az udvar felől lévő szélső falhoz újonnan 3 4/6 ölnyire az hosszában letett fundamentom után az fal magasságában nevelkedik" ${ }^{54} 1792$. december 30-án Podolányi Ferenc a kastélyra fordított addigi költségekről készített számadását benyújtotta a Directoratusnak. ${ }^{55}$ A Directoratus iratai szerint 1794. március 14-én Liechtenvalner József keszthelyi ács és meszes követ, fát, és kemendi cserepet kért az uradalomtól, de nem kapott, mivel azok az új kastélyhoz kellettek. ${ }^{56}$ 1794. április 9-én „Az Új kastélynak ezen folyó esztendőben elkészülendő részeibe Átjárókhoz, Ablaktokok, Táblák és padoláshoz szükséges fa, vagy kő minemőségek meghatároztattak" ${ }^{57}$ Ebben az évben Piestyánszky Ignác tiszttartótól fennmaradt az új kastély költségvetése, valamint egy arra vonatkozó adat, hogy egy "téglást" fogadtak az építkezéshez. ${ }^{58} \mathrm{Az}$ 1795. évből ismertek a kőhöz, a téglához, a vashoz és a fához, valamint a stukkókhoz szükséges drótok beszerzéséhez kapcsolódó megrendelések. 1796. január 25-én Sebestyén „ingenieur” a kőmüves munkákra szerződést kötött Eigner kőfaragóval, ${ }^{59}$ egy április 4-én kelt feljegyzésben szó esett egy bécsi mester rézmunkáiról, valamint az abban az évben elkészítendő kályhákról. Sebestyén járt Fuger (azaz Johann Heinrich Füger festő) úrnál „,a képfaragó académia directoratusánál” is „a menyezet jövendő kép elelosztódása végett"; szóba került, hogy a gróf saját maga fog a könyvtár mennyezetének kialakítására vonatkozóan vázlatot küldeni Fügernek. ${ }^{60}$ Philipp
Jakob Prokop bécsi képfaragó - azaz szobrász megbízásáról is fennmaradt adat ebből az időszakból, mégpedig abban az összefüggésben, hogy Sebestyén egyeztetni kívánt vele bécsi tartózkodása idején, de nem találta otthon. ${ }^{61}$

1796. április 20-án Eigner kőfaragó halála miatt Zitterbarth József keszthelyi kőfaragó szerződését terjesztették elö, ${ }^{62}$ Zitterbarth feladata volt valamennyi ajtó- és ablakkeret, a párkányok, a kutak és a figurális szobrok elkészítése. 1796. május 26án Fischer Márton bécsi „,képfaragás tudománybeli professzor úr" (Johann Martin Fischer) megküldte Sebestyén mérnöknek az általa készített szobrok árát. ${ }^{63} 1796$. augusztus 1-je körül az uradalmi építési irodában működő Rantz János György kőmívesmester kérelmet írt a grófnak, „hogy mindennemű építészetre való nézve csak egyenesen Ónagyságától függhessen", emellett a járandóságairól és a munkaszervezésről is szó esett az írásban. ${ }^{64}$ 1797-ben a feljegyzések szerint kályhákat hozattak Bécsből, ${ }^{65}$ amelyeket a kastély új szobáiban állítottak fel. ${ }^{66} \mathrm{Az}$ épület fütésére szolgáló cserépkályhák másik részét Pittermann József keszthelyi gelencsér készítette, akivel 1798-ban kötöttek szerződést, és akinek megadott minták szerint kellett dolgoznia. 1797-ben az új kastélyt teljesen bevakolták, lépcsőjét elkészítették, ${ }^{67}$ és padlásának padlózatát is kitapasztották. ${ }^{68} 1798$-ban Pernhard János soproni szobafestővel szerződést kötöttek a kastélybeli festési munkák kapcsán. ${ }^{69}$ Ugyanebben az évben Gyöngy József tiszttartó és Sebestyén Sámuel mérnök elkészítették a keszthelyi építkezésekhez addig felhasznált építőanyagok összeírását, és tervezetet készítettek arról, hogy a munkálatok befejezéséhez milyen anyagokra, és azokból mekkora menynyiségre lesz még szükség. ${ }^{70}$ Nem sokkal később Gyöngy tiszttartó meg is kezdte a következő évi építkezésekhez szükséges építőanyagok beszerzését. ${ }^{71} 1799-b e n$ sor került a kastély „grádicsrostélyának" - azaz lépcsőkorlátjának - a megrendelésére, ${ }^{72}$ ezeket a rozettás, klasszicizáló késő barokk vasrácsokat Dobrolán József keszthelyi lakatos készítette, és az ő munkája az ablaktalan, felső világítású „lámpás grádics" lépcsőházának a tetőrácsa is. ${ }^{73}$ Ezen tetőrács beüvegezéséhez az úrkúti Gasteigner János üveghuta-bérlőtől rendeltek 20 tábla különleges üveget darabonként 1 forint 10 krajcárért. $^{74}$ Ebből az évből fennmaradt a tiszttartó kimutatása a kastély már elkészült és még tervezett asztalosés lakatosmunkáiról, valamint az uradalmi mesterek fizetéseiről; fennmaradt a kasznár összeírása is az épülethez már felhasznált és még igényelt „materiák"-ról. ${ }^{75} 1799$. április 23-án az új kastély csatornáinak az elkészítésére szerződést kötöttek egy bádogossal. ${ }^{76} \mathrm{Az}$ új déli szárnyban a belső dí- 
szítési és berendezési munkálatok egészen 1804-ig elhúzódtak, ennek mestereit Péczely Piroska publikálta tanulmányaiban.

A gróf főúri státuszát, igényességét jól reprezentáló építkezések igen jelentős összegekbe kerültek, Laky István vice-exactor összeírásának tanúsága szerint csak 1803. január 1. és 1804. május 4. között 56593 forintot fordítottak a kastélyra. ${ }^{77}$

A rezidencia aszimmetrikus kialakítása miatt a más kastélyok esetében megszokott, az épület föszárnyának a középtengelyére szimmetrikus férfi oldal - női oldal elrendezés is megváltozott, amint azt a fennmaradt inventáriumok bizonyítják. Bár viszonylag ritka, nem példa nélküli az, hogy a kastély főszárnyához csak egy oldalszárny kapcsolódik L alakot formázva, ilyen például az 1786-ban emelt bükkösdi Petrovszky-kastély is. A főhomlokzati kialakítását tekintve rokon a keszthelyi kastély ezen periódusával az 1787-ben emelt U alaprajzú zalaszentgróti Batthyány-kastély - amelynek mai kocsiáthajtós terasza 19. század végi bővítés eredménye -, a mára lebontott, az archív képeken látható kialakítását 1790 és 1795 között elnyert marcaltői Esterházy-kastély, vagy az 1760-ban elkészült pétervásárai Keglevich-kastély.

1798-ban - amikor az újonnan emelt déli szárny esetében már a belső munkálatok zajlottak - Festetics (I.) György az átalakítással addig nem, vagy alig érintett keleti fószárny reprezentatív kiépítését is célul tüzte ki, amely a gróf elképzelései szerint a meglévő egyemeletes kastélyrész átalakítását és kétemeletessé tételét jelentette.

A földbirtokos az átépítés megtervezésére a bécsi akadémia professzorát, Andreas Fischer építészeti tanácsost, alsó-ausztriai fóépítészt kérte fel, aki még abban az évben el is készítette a terveket a gróf által megadott instrukciók alapján. ${ }^{78}$ Ezek a - mára elpusztult vagy ismeretlen helyen lappangó - tervek azonban úgy tünik, hogy nem nyerték el teljesen Festetics tetszését, mert Fischer javaslatainak a felhasználásával saját uradalmi kőmívesmesterével, Rantz János Györggyel is rajzoltatott terveket. Erről egy 1798 végén készült jegyzőkönyvben az alábbiakat olvashatjuk: „Minekutána Sebestyén inzsenér [mérnök] úr hazaérkezett őn.ga Rantz kőmüves mesterrel nem csak az egész kastélyt újra felvetette, hanem az új felosztásnak ideáját és arra építendő új emeletnek plánumát is professzor úr által javasolt gondolatoknak használásával lerajzoltatta. Nem csak a fenék- $\mathrm{s}$ fennálló rajzolat három felül, hanem az Durchschnitt [keresztmetszet] - is elkészíttetik, $s$ ha egyszer mind papiroson lészen, akkor ismét fog írni ôn.ga professzor úrnak s a dolog felül tovább értekezni." ${ }^{79} \mathrm{~A}$ kapcsolat azonban nem sokkal később megszakadhatott Fischerrel, mert a későb- biekben nem említik a nevét a keszthelyi kastély kapcsán.

A fent idézett 1798-as forrásban megnevezett tervlapok, vagy azok másolatai fennmaradtak a Festetics-levéltárban Rantz aláírásával, viszont egységesen az 1799-es dátum látható rajtuk. Az öt tervlapból álló sorozaton ${ }^{80}$ a kőmívesmester neve mellett azt olvashatjuk, hogy „Inventirt fon Herrn Gravn Festetits. Durchdem Johann Georg Rantz B. M. aber ausgearbeitet vor den Im Jahr 1799.", tehát a gróf tulajdonképpen maga "tervezte" a kastély átalakítását, Rantz csak formába öntötte azt müszaki szempontból. Az, hogy a megrendelő föúr kastélya kialakításáról határozott elképzelésekkel rendelkezett, nem volt szokatlan a korban. (De pontosan ugyanez történt nyolc évtizeddel később Keszthelyen is, amikor Festetics [II.] Tasziló építtette át és bővíttette ki a rezidenciát.) Arra is van példa, hogy a földbirtokos a neves építésztől megrendelt terveket saját ízlése szerint átalakíttatta, és az a változat került ténylegesen megvalósításra, ez történt például báró Harruckern Ferenc gyulai kastélybővítése esetében az 1760-as évek közepén. ${ }^{81}$ A jegyzőkönyvekből az is kiderül, hogy Festetics (I.) György a rezidencia építési munkái során személyesen felügyelte a kivitelezés minden részletét. (A Festetics-uradalmakban egyébként minden kisebb-nagyobb építési munkát központosítottak, a keszthelyi tisztiszék rendeletére 1799 júliusától valamennyi tervbe vett építkezés rajzát és költségvetését fel kellett terjeszteni az igazgatósághoz. „Ez a munkát is meggyorsítja, mert nem a kezdéskor kell a jóváhagyásra várni" - írták. ${ }^{82}$

A Rantz-féle 1799-es tervekből végül semmi nem valósult meg; ennek oka a gróf anyagi helyzetében keresendő, amelyet egyrészt a déli oldalszárny felépítése, másrészt az ekkor már Bécsben külön élő felesége, valamint a szintén a császárvárosban lakó László fia költséges életmódja is jelentősen megterhelt.

A tervlapokon látható homlokzatok a 18-19. század fordulójának egyre erősebben klasszicizmusba hajló késő barokk stílusát képviselik, gazdag füzérdíszükkel, az oromzaton álló kővázáikkal. A hálózatos kialakítású keleti homlokzatot az első és a második emeletet átfogó óriás pilaszterek tagolják. A gazdagon díszített háromtengelyes középrizalit a fópárkány fölé emelkedik, első emeletén magas, félköríves záródású ablakok, második emeletén pedig egyenes záródású ablakok sorakoznak, a rizalit ablakait az emeleti részeken két szintet átfogó kompozit fejezetü pilaszterek keretelik. A timpanonban a Festetics család címere látható füzérekkel övezve. Az oldalrizalitok szegmensíves oromzattal záródnak, amelyeken egy-egy allegorikus szoborcsopor- 
tot terveztek elhelyezni, a bal oldalin négy oroszlán vontatta kocsin ülő holdkoronás nőalak (amely az éjszakát jelképezi), a jobb oldalin pedig négylovas kocsin ülő napsugaras fejdíszü férfialak (amely a nappalt jelképezi) látható. $\mathrm{Az}$ épületet egyszerü magas tető fedi, csak a középrizalit feletti rész manzárdos kialakítású, ennek csúcsán Ceres szobra áll. A nyugati homlokzat középrizalitját négy darab két szintet átfogó ión oszlop díszítette volna, amelyeknek a tetejére - a rizalit második emelete elé - kőbábos mellvéddel ellátott erkélyt terveztek. A rizalitot kővázákkal díszített attika zárta volna le, amelyre órával ellátott, egy tengely szélességü, füzérekkel gazdagon díszített oromzat került volna. Kiemelendő, hogy a főszárny két végének - az oldalhomlokzatoknak - az első és második emeleti részei elé öt tengely szélességű, hat darab két szintet átfogó ión oszloppal ellátott, kőbábos mellvédes nyitott erkélyt terveztek, amelynek típusára nincs példa a magyar emlékanyagban. A Rantz-féle tervek stílusa, a rajtuk megjelenő építészeti kialakítás egyértelműen a Bécsben müködő Fischer professzor hatását tükrözik (10-13. kép).

További adalék az épület aszimmetrikus voltához és az északi szárny fel nem épüléséhez, hogy ez az 1799-es tervlap ${ }^{83}$ az akkorra már felépült déli szárny indítását fekete, azaz meglévő épületrészként jelölte, míg a meg nem valósult északi szárny indítását rózsaszínnel, azaz felépíteni tervezettként tüntette fel (14. kép).

\section{Festetics (I.) György kastélya} a leírások és az inventáriumok alapján

A Festetics (I.) György épületbővítésével immár megnövekedett alapterületű rezidencia első öszszeírásában, 1812-ben a kiskastéllyal együtt összesen 49 helyiségnek a berendezését vették számba. A leltárban említésre került - sorrendben - a gróf szobája, a nagy konyha, a nagy spájz, a kamra, a volt biliárdszoba. Itt minden bizonnyal az emelettel folytatódott a leírás: a zöld szoba, az inas szobája, a vörös szoba, a sárga szoba - amely az ifjú gróf volt szobája -, a biliárdszoba, a palota, a téli ebédlőszoba, a képes szoba, a grófné szobája, a gróf hálószobája, a gróf nappali szobája, a „második új szoba”, a "harmadik új szoba”, az inas szobája, a szobaleány szobája, az előszoba, a sekrestye, az ifjú gróf hálószobája, az ifjú gróf nappali szobája, és a gróf inasainak a szobája került említésre. Innen minden bizonnyal ismét a földszinttel folytatódott a lista: a kis kancellária, a kancellisták szobája, a protocollista szobája, a directionalis szobája, a tárnok szobája, a szolgálók szobája, az asztalnok szobája, a kulcsárné szobája, az inasok ebédlője, a lovászok ebédlője, az udvarnok szobája, a titkár szobája, a levéltáros szobája, és a palotába felvezető lépcső került említésre. Ezt követően a kiskastély következhetett: fáskamra, az inspektor lakása, a fegyveres kamra, a kertész szobája, a legény szobája, egy ún. harmadik új szoba, valamint Kegel és még egy lovászmester szobája is szerepelt az inventáriumban. A helyiséglista tanúsága szerint a kastély egyszerre volt a grófi család lakóhelye, valamint az uradalom igazgatási központja; ez a sok melléképület ellenére - ahová át lehetett volna helyezni az igazgatási funkciókat - egészen az 1883-1887-es átalakításig így is maradt.

1812-ben elkészült a már többször említett, a kastély akkori állapotát hitelesen bemutató alaprajz ${ }^{84}$ a rezidencia földszintjéről és pinceszintjéről. (Ez utóbbin látható a készítés dátuma; az első és - a könyvtárszárny esetében - a második emeletről készült alaprajz nem maradt fenn.) A felmérések minden bizonnyal egy kastélyleltár részeként készültek, és bár az alaprajzokon szereplő helyiségek számozottak, a hozzájuk tartozó összeírás - azaz a helyiségszámok feloldása - nem maradt fenn. (Bár 1812-ből maradt fenn kastélyleltár, annak számozása azonban nem feleltethető meg az alaprajz számozásának.) (15-16. kép)

1802-ben a Zeitschrift von und für Ungarn címü lap leírást közölt Keszthelyről, ebben azonban meglehetősen sok olyan adat található, amely a kutatások fényében nem bizonyult pontosnak. ${ }^{85}$

1809-ben Marmont tábornagy látogatta meg Festetics (I.) Györgyöt, az 1830-as években megjelent visszaemlékezései szintén azt támasztják alá, hogy a kastély nem épült ki teljesen a tervezett $U$ alakban: „A keszthelyi kastély szép, de nincs befejezve... helyét nem jól választották meg... egy terméketlen lapály választja el a kastélyt a tótól, melynek ott alacsony és iszapos a partja; a másik oldalon a kertek céljaira szolgáló terület nem alkalmas semmiféle növényzetnek." ${ }^{86}$

1815-ben Richard Bright, az 1814-es bécsi kongresszusról magyarországi körutazásra induló angol orvos járt Keszthelyen. ${ }^{87}$ 1818-ban Edinburgh-ban megjelent könyvében megemlékezett a birtokról, az akkoriban már egyre híresebbé váló - szintén Festetics tulajdonban lévő - hévízi gyógyfürdőről és a Georgikonról. Feljegyezte például, hogy a Georgikon fáskertjeinek a meglátogatása a kerti színházban rendezett rövid tánccal zárult, amelyet az intézet hallgatói adtak elő. Könyvében a kastély épületéről sajnos nem közölt képi ábrázolást, csak annak börtönéről, valamint a rezidenciától keletre fekvő manézsról. 


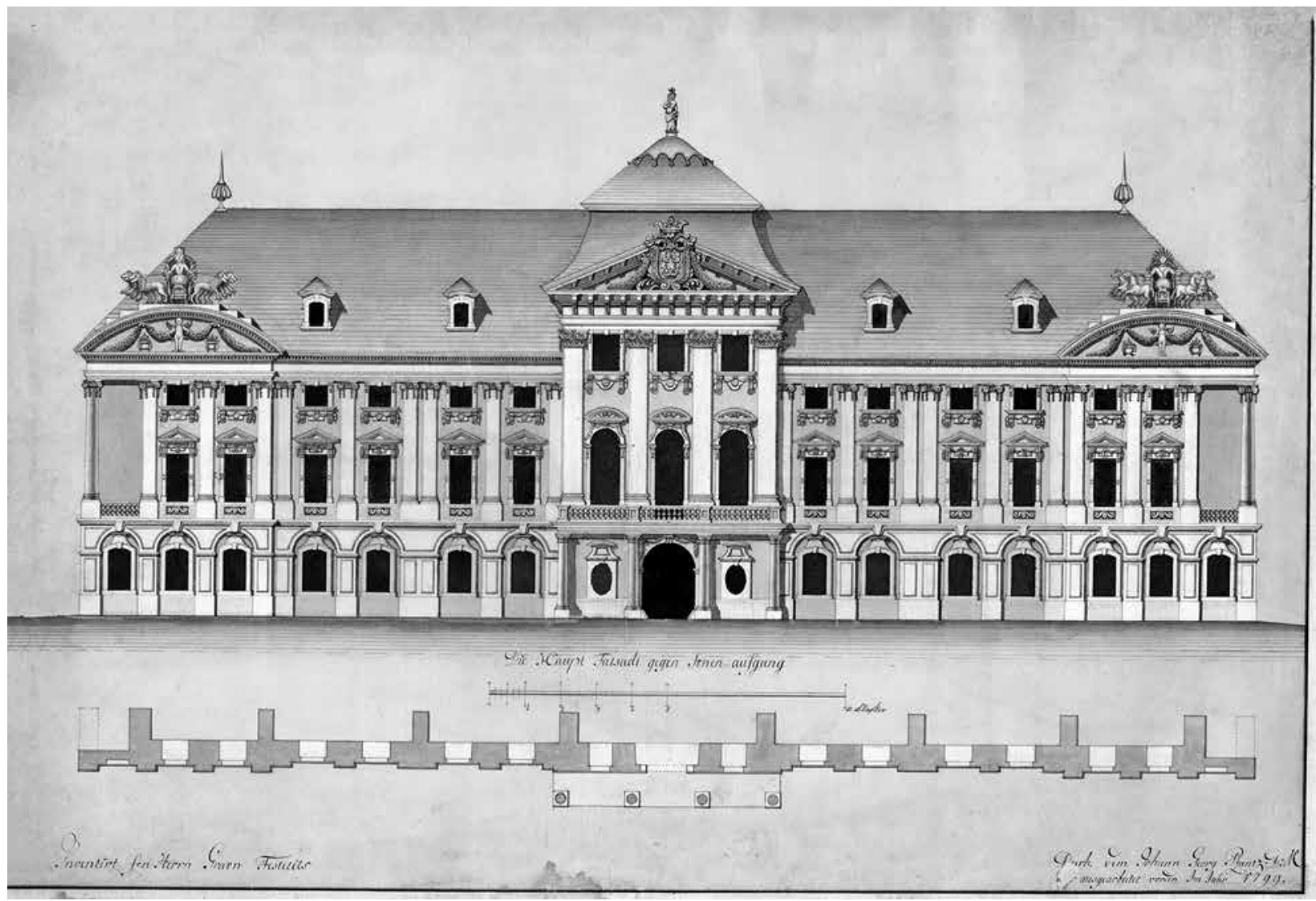

10. Rantz János György terve a kastély átépitésére, keleti homlokzat és alaprajzi részletterv, 1799. MNL OL T 3 - No. 273.

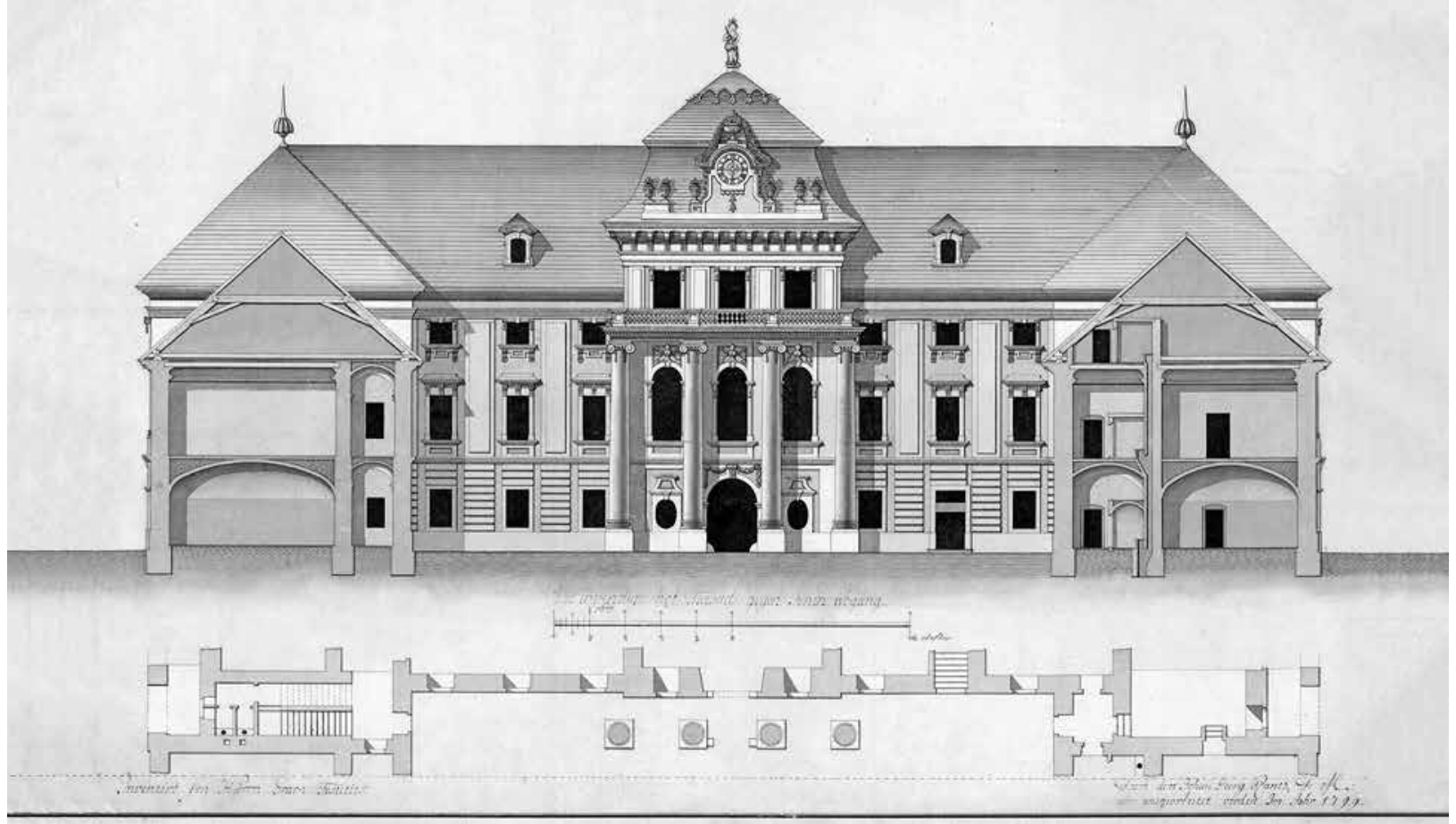

11. Rantz János György terve a kastély átépitésére, nyugati homlokzat, a hátranyúló oldalszárnyak keresztmetszete és alaprajzi részletterv, 1799. MNL OL T 3 - No. 274. 


\section{1819-1846 - GRÓF FESTETICS LÁSZLÓ (1785-1846) BIRTOKOSSÁGÁNAK IDEJE}

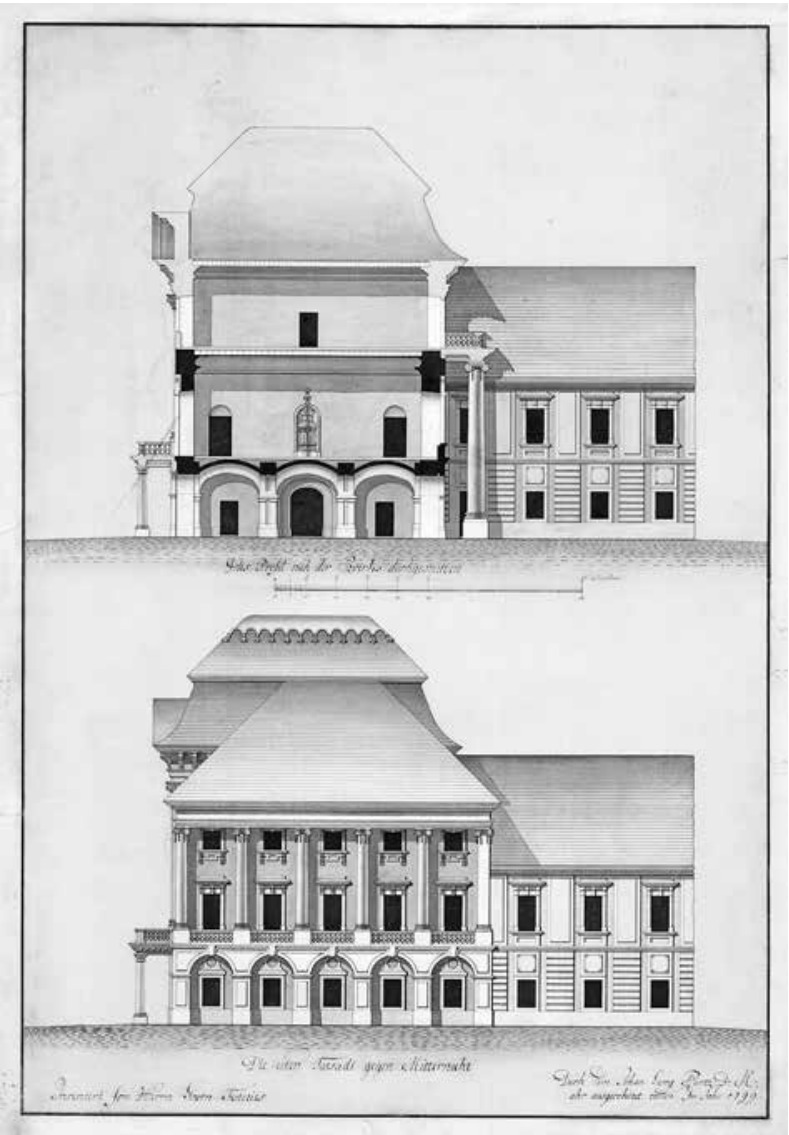

12. Rantz János György terve a kastély átépittésére, keresztmetszet (a szimmetriatengelyben) és az északi oldalhomlokzat, 1799. MNL OL T 3 - No. 275.

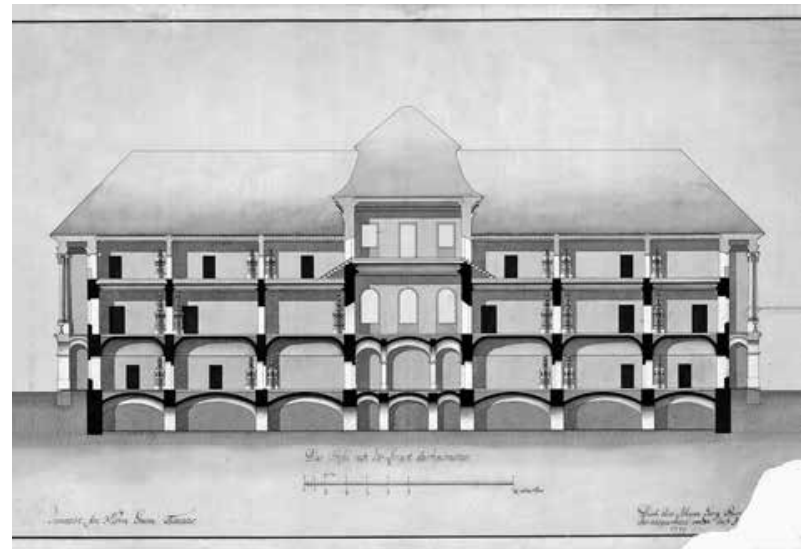

13. Rantz János György terve a kastély átépitésére, a keleti (fó)szárny hosszmetszete, 1799. MNL OL T 3-No. 276.
Miután 1819-ben elhunyt Festetics (I.) György, a keszthelyi hitbizományt egyetlen fia, Festetics László örökölte. Ő nem sokkal a birtok átvételét követően nagyszabású terveket dolgozott/dolgoztatott ki Keszthely város rendezésére, de a kastély kibővítésével és átépítésével kapcsolatban is határozott elképzelései voltak. Korábban, 1811-ben a keleti (fő)szárny átalakításához maga a gróf készített rajzot, ${ }^{88}$ mivel a korban a főnemesek képzéséhez az építészet oktatása is hozzátartozott; Festetics francia mintakönyvekből „ollózta össze” a kastélybővítés kevéssé sikerült „,tervét” ${ }^{89}$ Végül az elképzelések nem valósultak meg Festetics László egyre romló anyagi helyzete, állandó pénzzavara miatt.

Győry Zsigmond földmérő 1821 decemberében/1822-ben készített a tervezett kastélybővítésről egy helyszínrajzot. ${ }^{90}$ A tervlapon érdekes módon mindkét évszám szerepel ugyanazon az oldalon, az utóbbi évszám talán a terv frissítésének az időpontját jelöli. Ezen a rajzon világos rózsaszínnel tüntették fel a meglévő - és a tervek kútba esésével továbbra is megmaradó - állapotot, pirossal pedig a kétszeresére növelt hosszúságú - de ugyanúgy rizalitokkal tagolt - keleti (fő)szárnyat, amelynek az északi végére a déli szárny pandant-jaként, annak megtükrözésével egy új L alakú szárny került volna. (Fontos megemlíteni, hogy az aszimmetrikus kastély hat évtizeddel későbbi, 1883 és 1887 közötti Festetics [II.] Tasziló-féle kibővítése végül hasonló, additív, és nem szimmetria szerinti logika mentén valósult meg.) A nyugati kiforduló szárnyak végeire még keskenyebb bővítményeket is tervezett Győry, amelyek közül a déli egy négyzetes alaprajzú pavilonnal, az északi pedig egy új, nagyméretü, hosszan elnyúló melléképülettel kötötte volna öszsze a kastélyt (17. kép).

Ez az elképzelés hasonló formában, azaz a meglévő és a tervezett részek eltérő jelölésével Győry Zsigmond fél évvel korábban, 1821 májusában készített Keszthely várostérképére is rákerült már, ${ }^{91}$ ezen látszik igazán a tervezett északi, téglalap alaprajzú melléképület-együttes hatalmas kiterjedése.

Festetics László ha a kastélyét nem is, de a kert átalakítását megkezdte 1821-22-ben, azonban ez is félbemaradt, legalábbis Győry terveihez viszonyítva. 

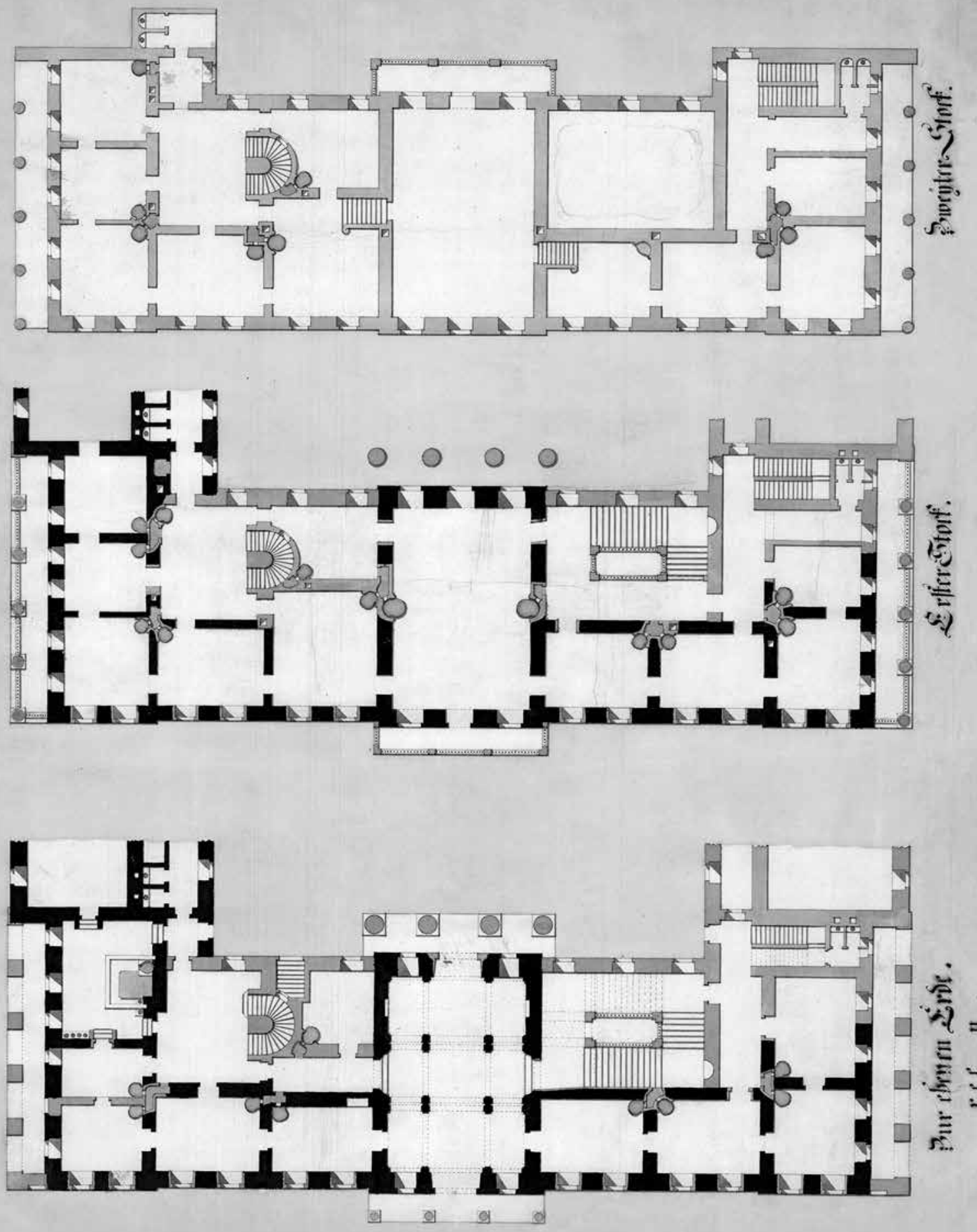

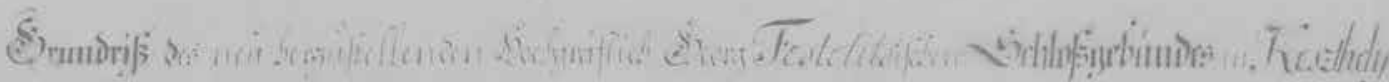

14. Rantz János György terve a kastély átépitéséről (földszint, első emelet, második emelet), a meglévő és az új részek jelölésével, 1799. MNL OL T 3 - No. 277. 


\section{1846-1883 - GRÓF FESTETICS (I.) TASZILÓ (1813-1883) BIRTOKOSSÁGÁNAK IDEJE}

Festetics László 1846-ban bekövetkezett halála után idősebb fiára, Festetics (I.) Taszilóra szállt a hitbizomány és vele a keszthelyi kastély. A gróf a katonai pályán lovassági tábornoki rendfokozatot ért el, és az Aranygyapjas-rendet is megkapta.

1857-ben jelent meg Ludwig Rohbock igen értékes forrásnak számító metszete ${ }^{92}$ Keszthelyről, amelyen a kastély keleti homlokzata is látható, amelyet azonban részben kitakart az elötte lévő - a lebontott Szent Márton-templomból megmaradt torony, valamint az a domb, amelyen a torony állt. (1880-ban a tornyot lebontották, és a dombot is elhordták.) (18. kép)

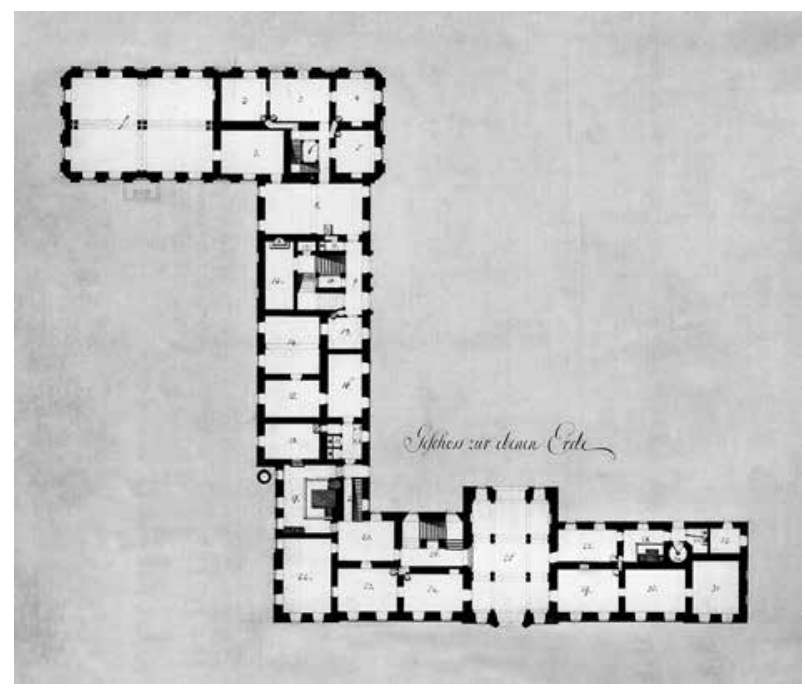

15. A kastély felmérési rajza, földszint, 1812. MNL OL T 3 - No. 333

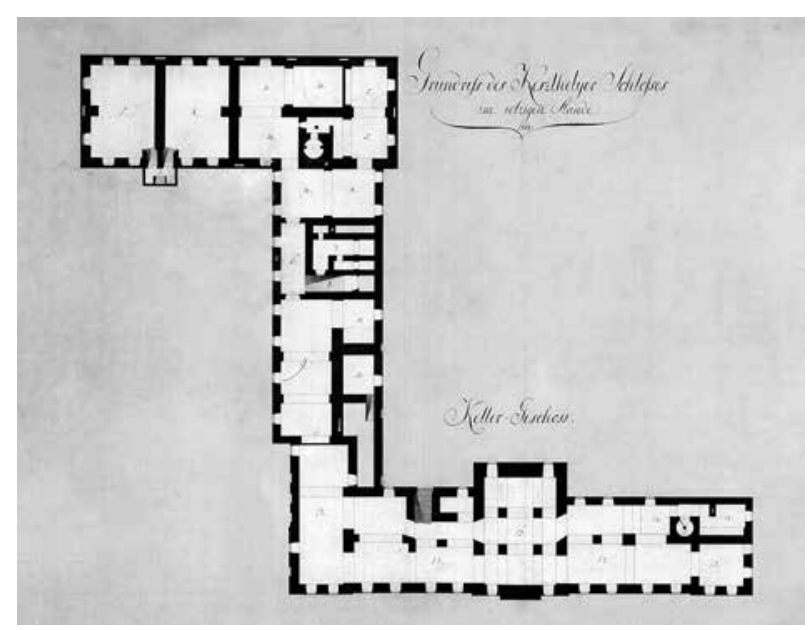

16. „A keszthelyi kastély jelenlegi állása”, pince [Grundriss des Keszthelyer Schlosses im ietzigen Stande], 1812. MNL OL T 3 - No. 332. 1858-ban pedig elkészült a már említett kataszteri térkép, ${ }^{93}$ amely fontos információval szolgál a kastély és parkja akkori kialakításáról (19. kép).

\section{Festetics (I.) Tasziló épitkezései}

A levéltári források tanúsága szerint 1866-ban Festetics (I.) Tasziló átalakításokat végeztetett a kastélyon, a feljegyzések kőműves-, festö-, stukkátor-, asztalos-, lakatos- és üvegesmunkákat is említenek. ${ }^{94}$ Új vízvezetékrendszer készült az épületben,

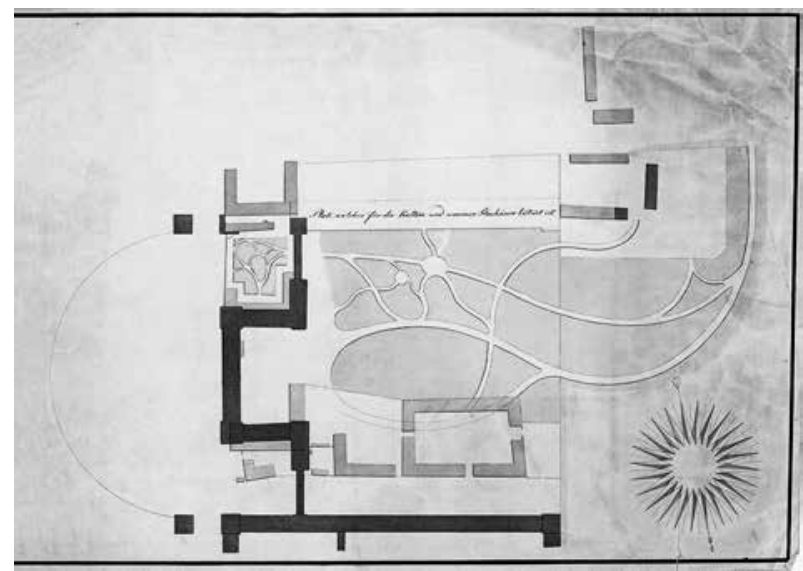

17. Győry Zsigmond helyszinrajza a kastély bövitéséröl [Ein Theil der Keszthelyer Schloss-Bau-Anlage], 1821/1822. MNL OL S 68 No. 192.

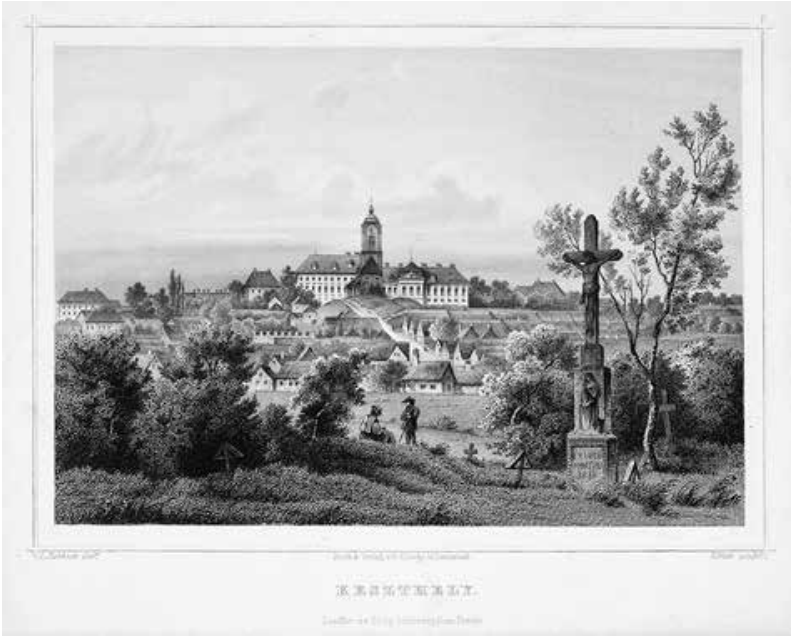

18. Ludwig Rohbock metszete Keszthelyröl. Darmstadt, DruckEVerlag v. G. G. Lange, [1857.] OSzK Kisnyomtatványtár, 45e nr55 
a mellékhelyiségeket felújították, és a szobákat is kifestették, egy levélben „újonnan berendezett urasági fénymázos szobák"'-ról is szó esett. A függönyök és a karnisok számlái azt bizonyítják, hogy a berendezés korszerúsítésére is sor került a termekben. Az adatok alapján úgy tünik, hogy a gróf részben az időszakonként esedékes felújítást és technikai korszerüsítést végeztette el ekkor a rezidencián.

Sor került a kastély külső megjelenését érintő átalakítási munkákra is: ekkor építették - a nyugati homlokzatról 1880-ban, az egykori Szent Mártontemplom a fotón még látható tornyának lebontása előtt készült - archív képen megfigyelhetö „galériát", vagy ahogyan a forrásokban szintén említésre került, ,,igen nagy üveges folyosót" is..$^{95}$ Ezen folyosó kialakításáról tanúskodik Victor Rumpelmayer egyik datálatlan, de biztosan 1883-ban készült - még a régi állapotot megörökítő - nyugati homlokzati felmérése is. ${ }^{96} \mathrm{Ez}$ a bővítmény egy az udvari oldalon - a középrizalit előtti részt kivéve - L alakban végighúzódó, a földszinten öntöttvas oszlopokon nyugvó nyitott, az emeleten pedig vasszerkezetes, függönyfalas, üvegezett folyosó volt, és a keleti főszárny, valamint a déli oldalszárny egymásból nyíló - két traktusra felfüzött - szobái közötti közlekedést volt hivatva megkönnyíteni. Az új bővítményen a romantikus historizmus stílusjegyei figyelhetók meg, különösen az előtetőn.

Az építési munkálatokhoz szükséges anyagok leszállítását általában Friedrich Flohr bécsi építész igazolta, minden bizonnyal ő volt a tervezője a keszthelyi kastély 1866-os átalakításának - bár általa szignált tervrajz nem maradt fenn -, és a megbízás részeként a kivitelezési munkák felügyeletét is ellátta. Flohr volt a tervezője Festetics (I.) Tasziló unokaöccse, Festetics Jenő 1870-es években felépült zalaújvári kastélyának is. ${ }^{97}$ A Festetics családnak több ízben dolgozó építész gróf Festetics (II.) Györgyné Erdődy Eugénia grófnő bécsi palotájának a munkálatainál is közreműködött a források tanúsága szerint. ${ }^{98}$

\section{Festetics (I.) Tasziló kastélya a képi források alapján}

1871-ben Metzl Kamill grófi szakács a kastély keleti homlokzatáról egy ceruzarajzot készített, ${ }^{99}$ amelyet Timár Rózsi fényképész 1942 novemberében lefotózott; a fényképről ma a Helikon Kastélymúzeum őriz egy másolatot. ${ }^{100}$ Ezen a rajzon már az 1866-os átalakítás után látható a kastély, és ugyanezt az állapotot tükrözi a keleti homlokzatról 1883 elött készített fénykép is. Az 1857-es Rohbock-féle metszettel

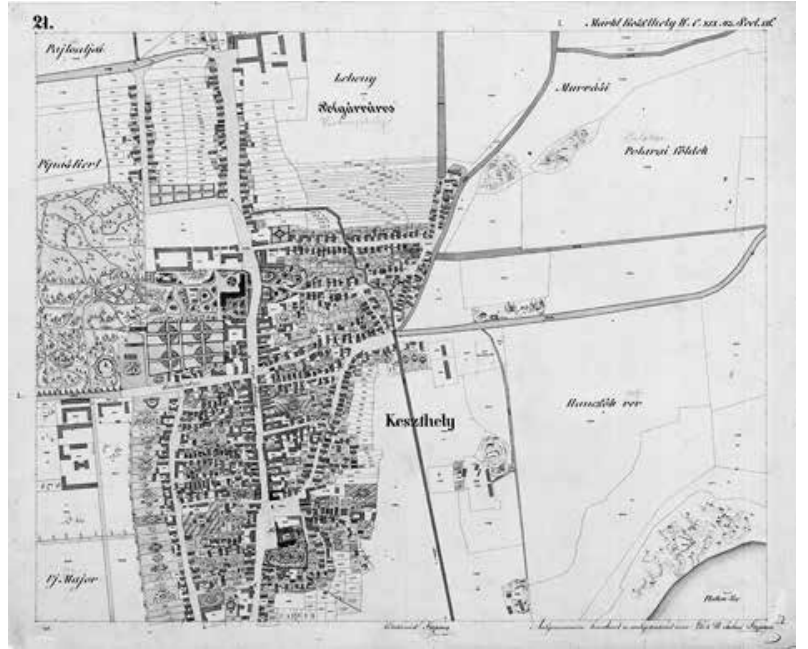

19. A kastély, melléképületei és parkja Keszthely kataszteri térképén, 1858 [Markt Keszthely sammt Ortschaften Polgárváros, Cserszeg. Tomay und Puszta Fenék in Ungarn, Oedenburger Distrikt, Zalaer Comitat], 1858. MNL OL $S 78$ 312. téka 32. szelvény

összehasonlítva az 1871-es Metzl-féle ceruzarajzot, a következőképpen foglalható össze a Festetics (I.) Tasziló-féle átépítés keleti homlokzatot érintő része: a minden bizonnyal Friedrich Flohr által tervezett historizáló átalakításnak köszönhetően a kéttengelyes sarokrizalitok sokkal erősebb hangsúlyt kaptak, új, manzárdos kialakítású tetővel látták el őket, főpárkányaik fölé baluszter került, amelyek közepén díszes neobarokk kereteléssel ellátott ovális ablakokat is elhelyeztek. (A nyugati homlokzat bal oldali rizalitja is ekkor nyerhette el hasonló - manzárdtetős, neobarokk keretelésű ovális tetőablakos - kialakítását, amelyről Rumpelmayer már említett 1883-as felmérése tanúskodik.) Úgy tünik, hogy a középrizalit timpanonja ekkor kapta a fogazatos díszítést, és a középrizalit félköríves emeleti ablakai fölé is ekkor került a lapos háromszög-szemöldök. (A nyugati homlokzat ugyanilyen kialakítású díszítőelemei szintén ekkor készülhettek.) A középrizalit emeleti középső nyílása előtt korábban nem volt erkély, a rajzon látható új, konzolokon nyugvó, a sarokrizalitok balusztereihez hasonló mellvéddel ellátott erkélyt is ekkor alakíthatták ki, és a mellette lévő egy-egy nyílás alatti balusztereket is ekkor helyezhették el. Zsalugáterekkel - amelyeket nyáron használtak, és a kor általános szokása szerint télen egy második, üvegezett külső ablaktáblát tettek a helyükre - szintén ekkor láthatták el az épület ablakait. (A dús falombozatok tanúsága szerint a Rohbock-féle metszet is minden bizonnyal nyáron készült, azon azonban még nem jelöltek zsalugátert.) (20-22. kép) 
(I.) Tasziló gróf építkezése után készült el az a már említett részletes leltár, amely azt is megadta, hogy az egyes helyiségek pontosan melyik részében voltak a kastélynak, és azt is sokszor megem- lítette, hogy melyik helyiségből és melyik égtáj felé nyíltak. A magyar nyelvü - néhány német szót is tartalmazó - inventáriumot valamikor 1866 és 1872 között készítették. ${ }^{101}$

\section{1883-1933 - HERCEG FESTETICS (II.) TASZILÓ (1850-1933) BIRTOKOSSÁGÁNAK IDEJE}

A gyermektelen gróf Festetics (I.) Tasziló 1883. február 5-én bekövetkezett halála után hitbizományát unokaöccse - gróf Festetics (II.) György legidősebb fia - gróf Festetics (II.) Tasziló örökölte. Az eredeti öröklési rend szerint a hitbizomány öccsére, a nála két héttel később elhunyt (II.) Györgyre szállt volna, azonban a fivérek között 1867. november 27-én megkötött egyezség alapján - amelyet a király 1868. március 14-én hagyott jóvá, és 1868. október 1-jén

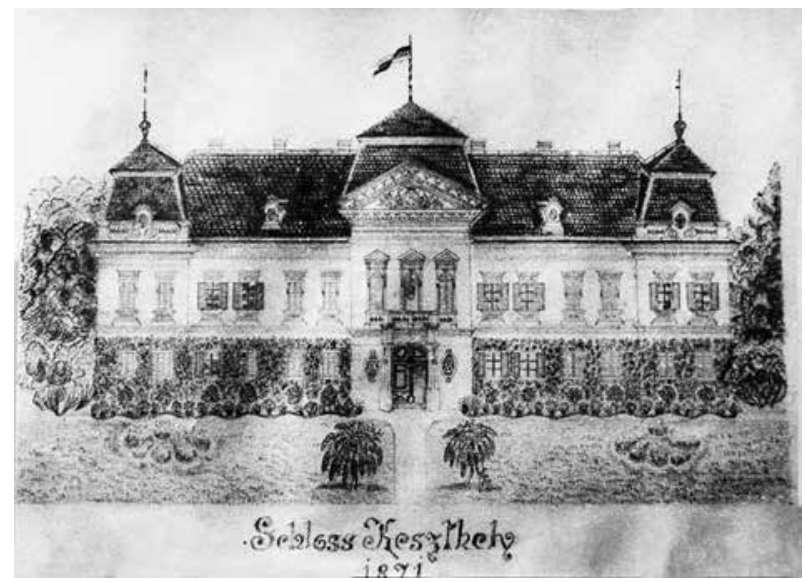

20. Metzl Kamill grófi szakács ceruzarajza a kastély keleti homlokzatáról, 1871. Helikon Kastélymúzeum C 2907 53. sz. köteg

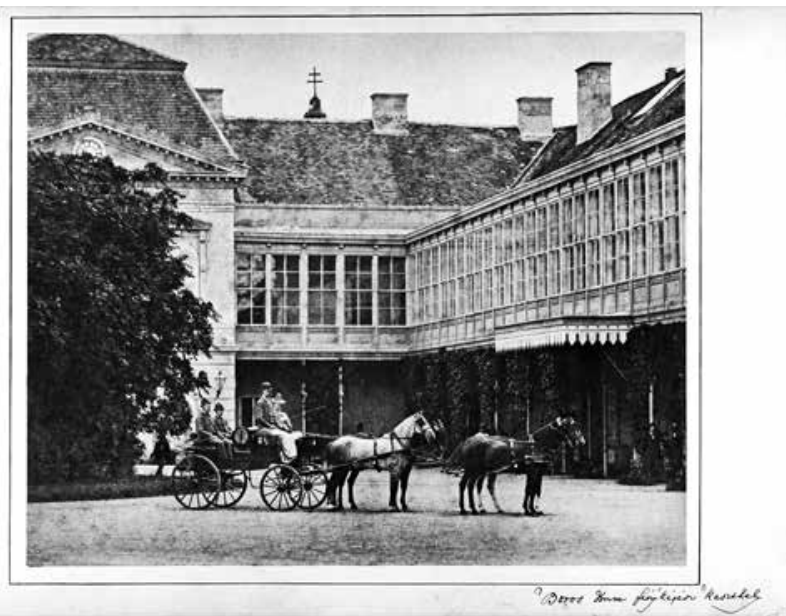

21. A kastély nyugati (udvari) oldalának déli része a Rumpelmayer-féle átépités előtt Boros Imre keszthelyi fényképész fotóján, 1880 elött.

MNL OL P 240 1. tétel - a. altétel-Nr. 488. kiadott okiratában erősített meg ${ }^{102}$ - (II.) Tasziló lett a közvetlen örökös az (I.) Tasziló 1874. május 11én kelt végrendeletében foglaltak szerint, amelyet 1879-ben és 1880-ban fiókvégrendeletekkel is kiegészített a gróf. ${ }^{103}$

Festetics (II.) Tasziló politikai szerepet nem vállalt, cs. és kir. kamarási és valóságos belső titkos tanácsosi, majd 1895-től m. kir. fôpohárnokmesteri, 1904-től pedig m. kir. főudvarmesteri címet viselt, és 1896-ban elnyerte az Aranygyapjas-rendet is. A közéletben a Balatoni Szövetség alapítójaként és a Balatoni Társaság fővédnökeként, valamint híres lótenyésztőként és sikeres versenyistálló-tulajdonosként volt ismert. 1911-ben a földbirtokost I. Ferenc József király - különleges kegyként - magyar hercegi rangra emelte.

A keszthelyi kastély legjelentősebb átépítése és kibővítése Festetics (II.) Tasziló nevéhez füződik. A beruházást elsősorban az indokolta, hogy a gróf 1880. június 2-án feleségül vette az előkelő skót hercegi családból származó Lady Mary Hamiltont, Albert monacói trónörökös - majd I. Albert néven 1889-től uralkodó herceg - korábbi feleségét, amely házassággal több európai uralkodócsaláddal is rokonságba került. Ily módon jelentősen megnőtt az igény a kastély kialakításának és berendezésének reprezentatívabbá tételére, a cizelláltabb funkciókat ellátó, ily módon nagyobb alapterületű lakókörnye-

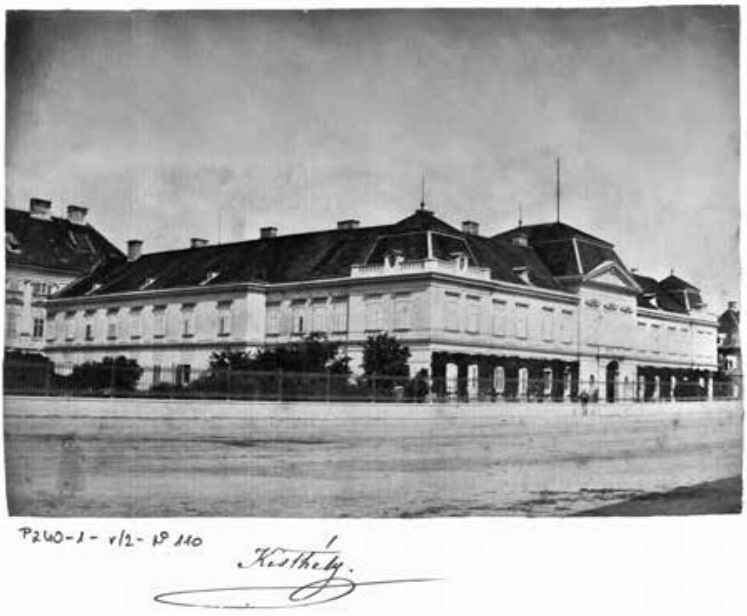

22. A kastély keleti homlokzata a Rumpelmayer-féle átépités előtt, 1883 előtt. MNL OL P 240 1. t. -r. 2 -No. 110. 


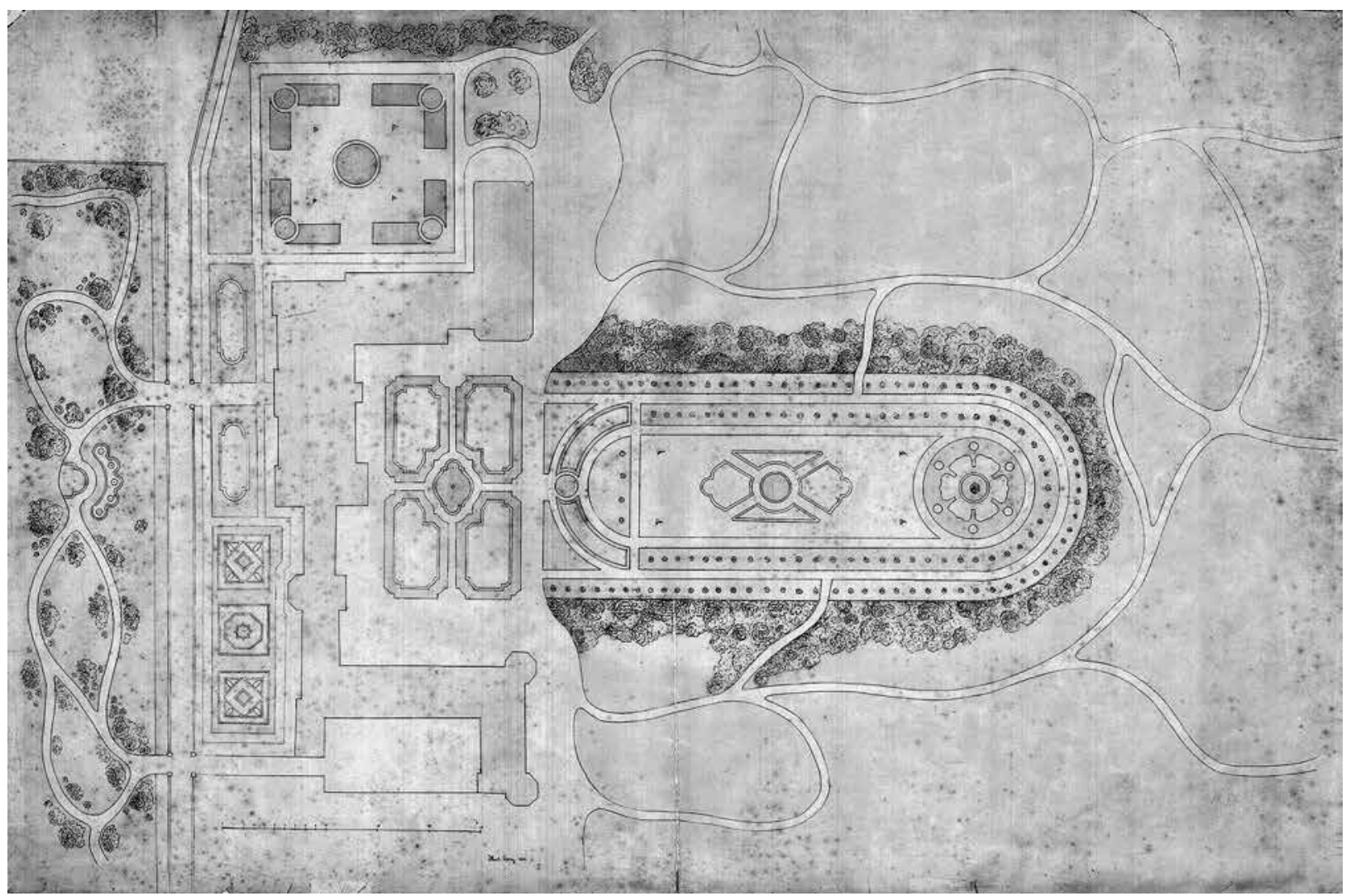

23. Karl Lang fókertész terve a park kialakitásáról, amelyre rákerült a kiböviteni tervezett kastély új alaprajzi kontúrja is, 1883. MNL OL T3 - No. 560.

zet kialakítására, valamint a vendégfogadások színvonalának emelésére.

\section{A kastély harmadik épitési periódusa}

A kastély kibővítésének a logikája sok tekintetben a Festetics (II.) Tasziló nagyapja, Festetics László idejében, 1821-ben készült bővítési vázlaton látható alaprajzi elrendezést követte. Az 1883 és 1887 között lezajlott munkálatok során a keleti főszárnyat hosszában észak felé megkétszerezték, és az 1755 óta folyamatosan tervezett északi szárny - igaz, más formában és jóval jelentősebb léptékben - végül elkészült. Alaprajzi szempontból nem volt példa hazánkban kastély ugyanilyen jellegü kibővítésére, ugyanakkor felfedezhető hasonlóság például az iszkaszentgyörgyi Amade-Bajzáth-Pappenheim-kastély 1736-ban első ízben említett barokk kori fóépületének később több ízben történt kibővítésével, amelyek közül léptékét tekintve a legjelentősebb az 1904 és 1908 között Gabriel Seidl müncheni építészprofesszor tervei alapján történt historizáló, neobarokk és klasszicizáló stílusjegyeket hordozó kiépítés, amely több mint kétszeresére növelte az épület alapterületét a régi rész végé- hez meglehetôsen szokatlanul kapcsolódó új, három szárnyból álló épületrésszel (23-24. kép). ${ }^{104}$

A keszthelyi kastély historizáló stílusú, neobarokk és neorokokó átépítésének a terveit Victor Rumpelmayer bécsi építész készítette el, ugyanakkor a fennmaradt levéltári adatok (és az épület kialakítása) fényében úgy tűnik, hogy Festetics szinte társtervezőnek tekinthető. Mivel a később bemutatandó - a Magyar Nemzeti Levéltár Országos Levéltárában őrzött - építési-kivitelezési szerződés

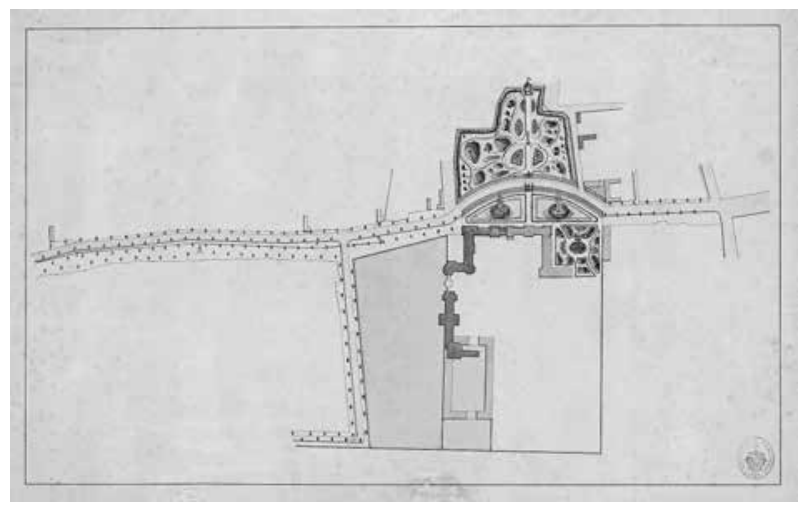

24. Riedl Ödön uradalmi föerdész terve Keszthely város belterületének rendezéséröl, részlet a kastély környékével, 1883. MNL OL S 68 No. 193., másolata OSzK TK 521. 


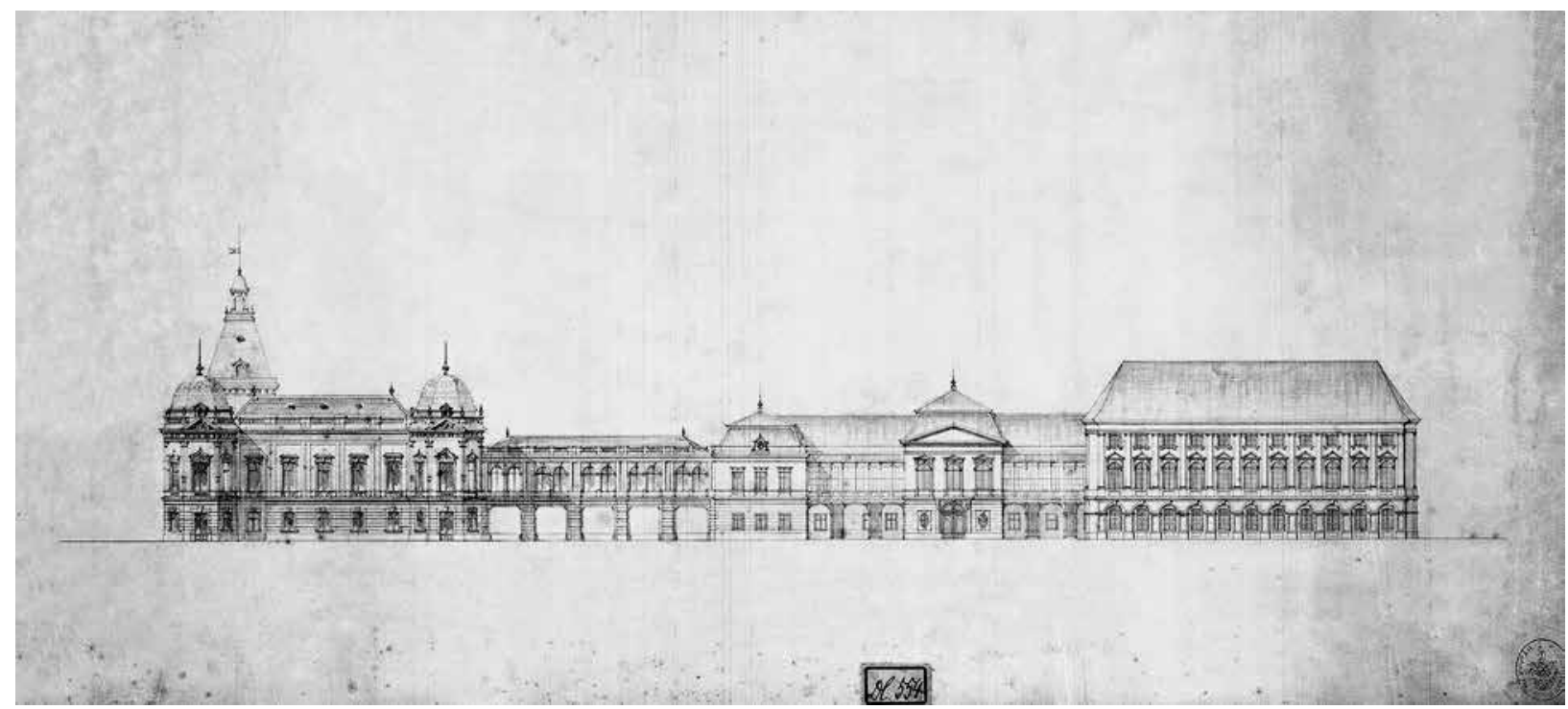

25. Victor Rumpelmayer terve a kastély kibövitésére a régi szárny meglévó állapotának ábrázolásával, nyugati homlokzat, [1883.] MNL OL T3 - No. 554.

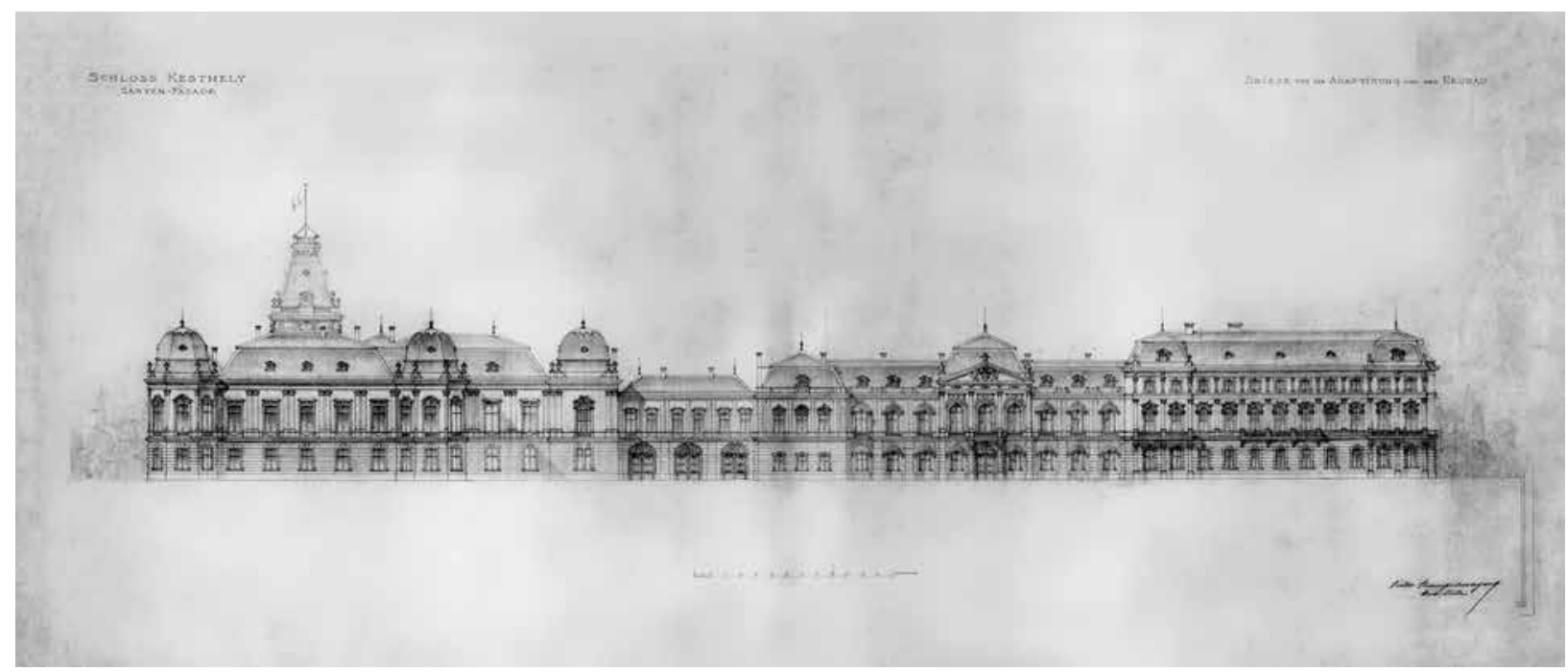

26. Victor Rumpelmayer terve a kastély átalakitására és kibővitésére, nyugati homlokzat, [1883.] MNL OL T3 - No. 551.

rendkívül pontos és aprólékos iránymutatást ad a kivitelezés tekintetében, a földbirtokos minden bizonnyal már a tervezés során is igen pontos előírásokkal szolgált az építész számára. (Magára a tervezésre vonatkozó szerződés nem maradt fenn a Festetics család levéltárában.)

A Pozsonyban született Victor Rumpelmayer (1830-1885) régi pozsonyi kőműves családból származott, apja pedig szobrászként működött. A müncheni Polytechnikumot végezte el, majd a bécsi Képzőművészeti Akadémia hallgatója lett Ludwig Lange professzornál, a diploma megszerzése után pedig Párizsban dolgozott, amely főleg belsőépítészeti munkásságán hagyott nyomot. Az 1870-es évekre elismert mestere lett a bécsi és pozsonyi felsőbb körök lakóházainak (például a pozsonyi Pálffy-palota ter- veit készítette el), valamint diplomáciai épületeknek (ő tervezte a bécsi német és angol nagykövetségi palotákat). ${ }^{105}$ Múvészeti befolyást főként a korai historizmus mesterei gyakoroltak rá, különösen van der Nüll és Sicard von Sicardsburg, akiknek az irodájában dolgozott önállósodása előtt. A keszthelyi kastély kibővítése és átalakítása az egyik legnagyobb munkája volt, Magyarországon a lengyeli Apponyikastély átépítésének a megtervezése is hozzá köthető. Bulgáriában a szófiai királyi palota és a Várna mellett a Fekete-tenger partján emelt Euxinograd kastély tervezése füződik a nevéhez. ${ }^{106} \mathrm{~A}$ keszthelyi kastély stíluselemeit tekintve ezeknek az épületeknek a sorába jól illeszkedik: a homlokzati felületeket - amelyeket sokszor kváderezéssel vagy sávozással osztott fel - faltükrökkel vagy falsávokkal keretelte. 
Mozgalmas, törtvonalú szemöldökpárkányokat emelt ki a falsíkból, amelyeket többnyire figurális plasztika díszít finomvonalú, rokokó dekorációval. Nagyobb épületek esetében előszeretettel tervezett emeleteket átfogó pilasztereket, többnyire kompozit fejezetekkel. Szabadon álló épületeire, főként kastélyaira jellemző még a változatos kontúrvonal, a szimmetrikus kialakítás elhagyása, azonban az egy homlokzaton belül is gyakran váltogatott különböző keretelések ellenére is mindig harmonikus és nyugodt maradt az összkép.

\section{A fennmaradt épitészeti tervek}

Victor Rumpelmayertől kilenc tussal készült tervlap maradt fenn, ${ }^{107}$ egyet kivéve minden tervlap szignált, és öt tervlap datált is (Bécs, 1883. augusztus). A tervlapok a kastély homlokzatait ábrázolják, három esetben egy-egy épületrész metszetét is megjelenítve $^{108}$ (25-33. kép).

Mivel a kastély átalakításáról és kibővítéséről nem maradtak fenn Rumpelmayer alaprajzi elrendezésre vonatkozó tervei, csak az 1812-ből fennmaradt földszinti kastélyalaprajz és a 20. század második feléből származó felmérési tervek ${ }^{109}$ összehasonlításával rajzolódik ki a munkálatok tartalma. $\mathrm{Az}$ alaprajzok változását elemezve megállapítható, hogy a barokk kori (fö)szárny nyugati traktusát mind a földszinten, mind az emeleten teljesen újjáépítették, és ezen munkálatok eredményeként a kastély nyugati (udvari) homlokzata nyugatabbra került, egészen a Festetics Kristóf-féle barokk kori és a Festetics (I.) György-féle klasszicizáló késő barokk kori szárnyak csatlakozási pontjának a vonalába.

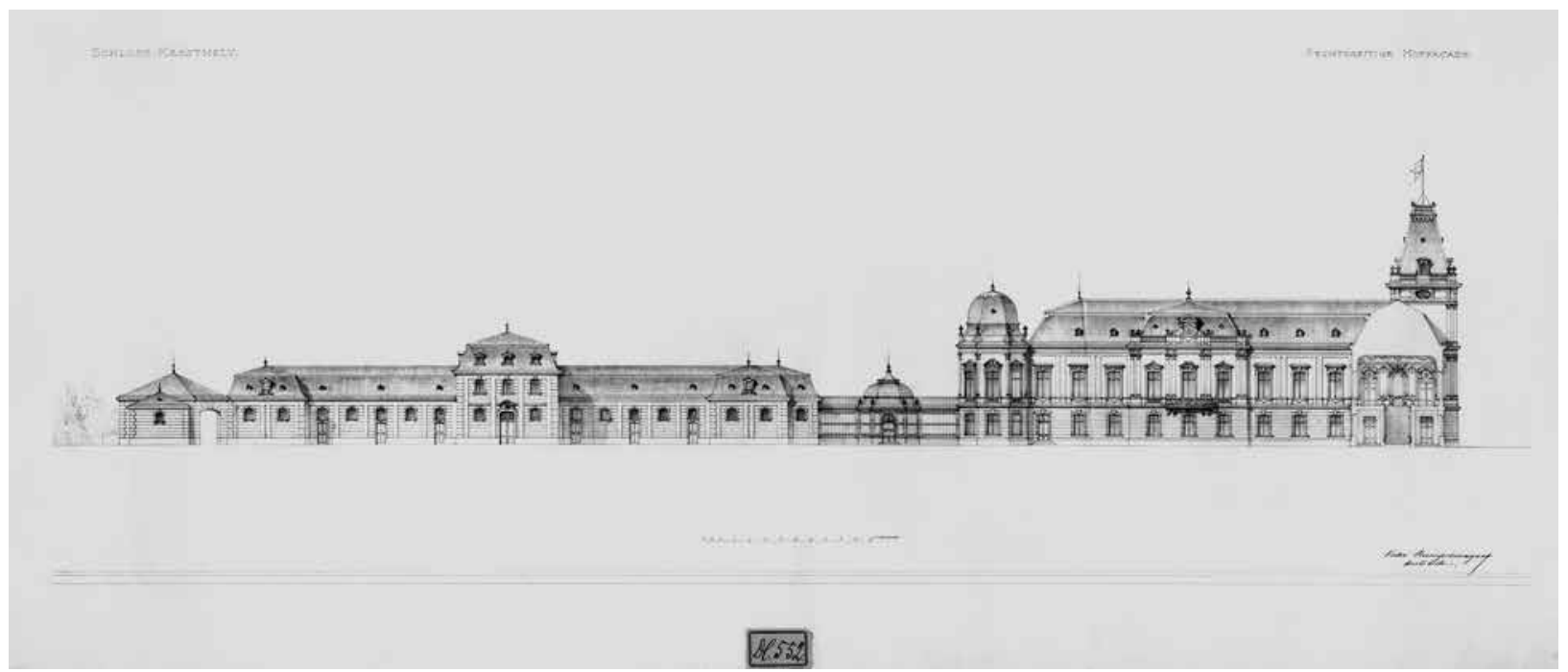

27. Victor Rumpelmayer terve a kastély kibôvitésére, az új északi kastélyszárny déli homlokzata, valamint a hozzá nyugati irányból nyaktaggal kapcsolódó - utóbb a föszárnytól távolabb, nyaktag nélkül megépüllt-istálló-kocsiszín épületének déli homlokzata, [1883.] MNL OL T3 - No. 552.

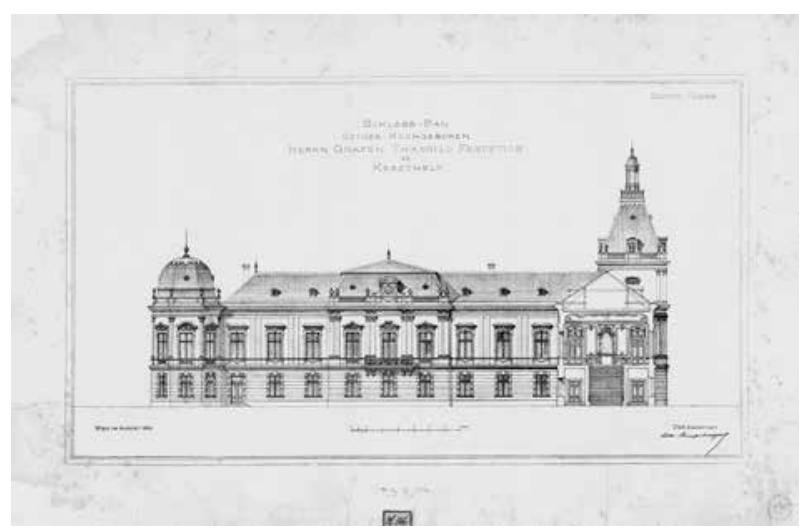

28. Victor Rumpelmayer terve a kastély kibôvitésére, az új északi kastélyszárny déli homlokzata, 1883. MNL OL T3 - No. 546.

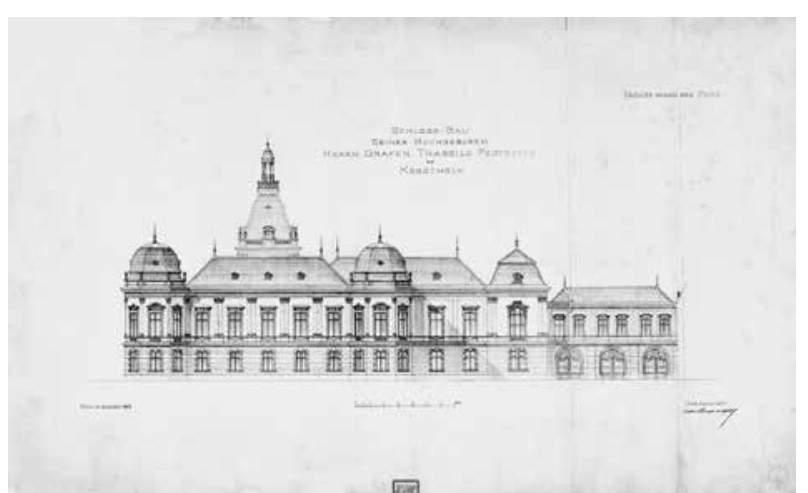

29. Victor Rumpelmayer terve a kastély kibóvitésére, az új északi kastélyszárny nyugati homlokzata; a terv szerint az épület északkeleti sarkára egy négyzetes alaprajzú - meg nem valósult - torony került volna, 1883. MNL OL T3 - No. 545. 


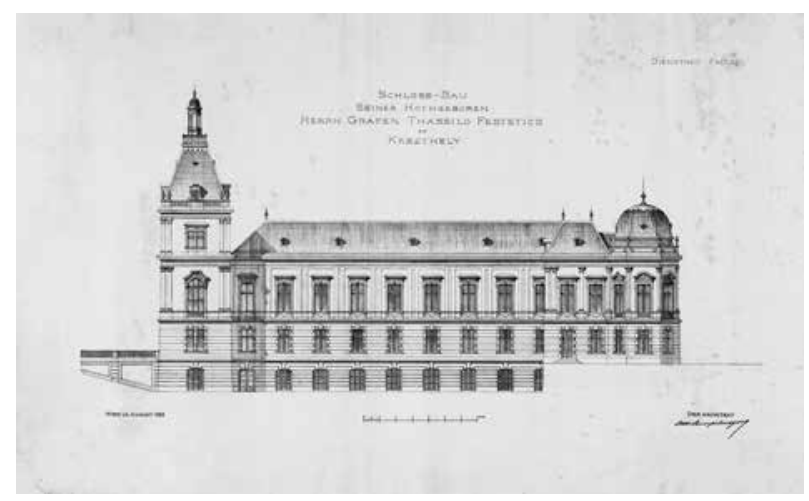

30. Victor Rumpelmayer terve a kastély kibővitésére, az új északi kastélyszárny északi homlokzata az északkeleti sarokra tervezett - meg nem valósult - négyzetes alaprajzú toronnyal, 1883. MNL OL T3 - No. 547.

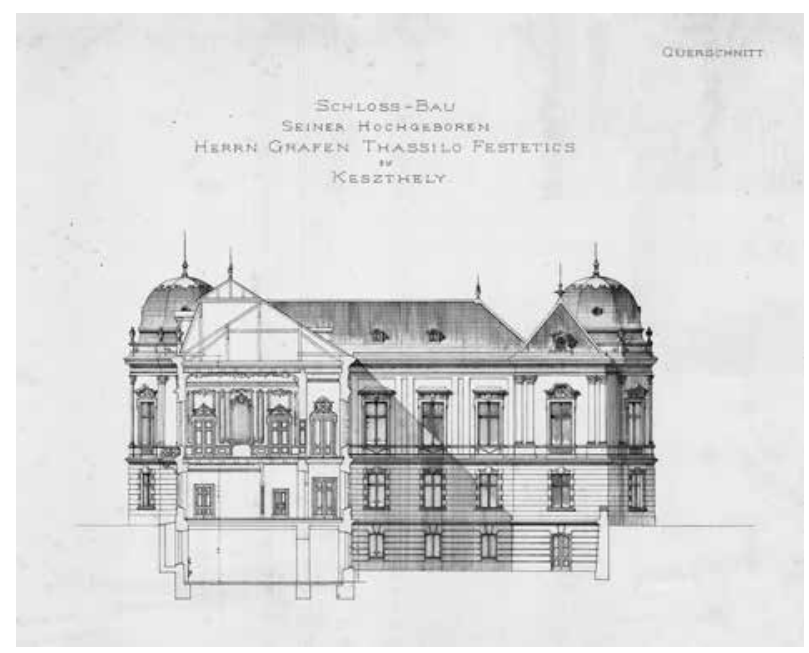

31. Victor Rumpelmayer terve a kastély kibővitésére, az új északi kastélyszárny kiforduló nyugati szárnyrészének keleti homlokzata és az északi kastélyszárny keresztmetszete, 1883. MNL OL T3 - No. 548.

A szűk nyugati traktus kibővítésének az igénye első ízben Rantz 1799-es tervén látható, ${ }^{110}$ a megvalósítás azonban több mint nyolc évtizedet váratott magára. Ez az átépítés csak a középrizalit földszintjét teljesen elfoglaló kocsiáthajtót, valamint a felette elhelyezkedő dísztermet (nagyebédlőt) nem érintette, ugyanis a rizalit eredetileg is előrelépett a nyugati homlokzat síkjából. A nyugati teremsor új nyugati falait viszont egészen a régi rizalit homlokzati síkjáig kitolták. Csak ekkor kerültek egy síkba a középrizalittól északra és délre húzódó homlokzati szakaszok, ugyanis ezek meglepő módon a kezdetektől, a Festetics Kristóf általi felépítés óta aszimmetrikusak voltak, ugyanis az északi szakasz síkja valamennyivel bentebb volt a déli szakasz síkjánál. (Ezt az anomáliát több meg nem valósult terv is szerette volna korrigálni.) A traktusbővítés tette lehetővé a régi lépcsőház tágasabbá tételét, amelynek következtében új lépcső beépítésére is lehetőség nyílt.

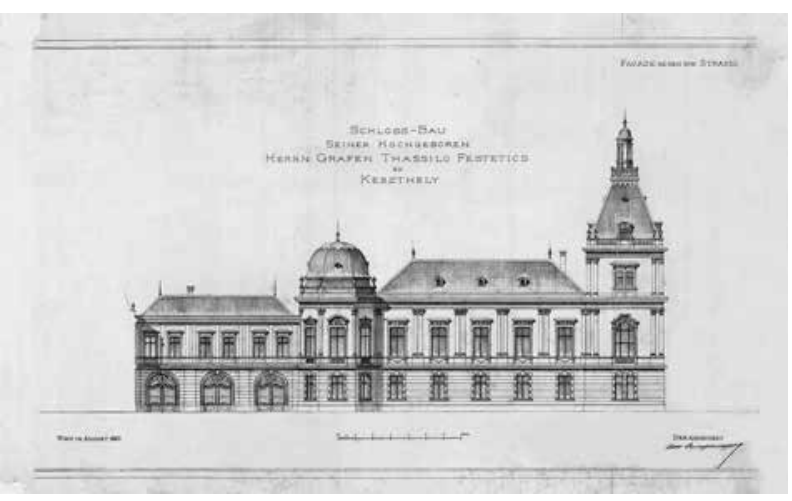

32. Victor Rumpelmayer terve a kastély kibővítésére, az új északi kastélyszárny keleti homlokzata az északkeleti sarokra tervezett - meg nem valósult - négyzetes toronnyal, 1883. MNL OL T3 - No. 544.

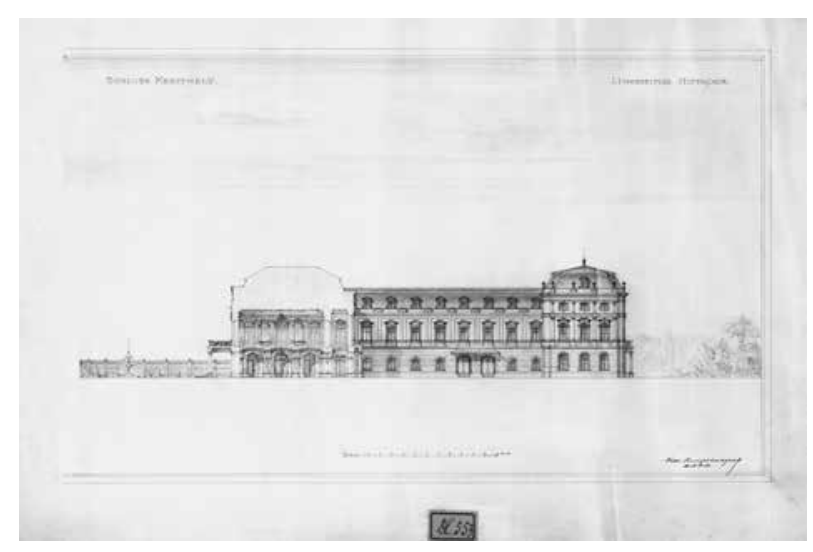

33. Victor Rumpelmayer terve a kastély átalakitására, a régi déli oldalszárny északi homlokzata és a régi keleti szárny keresztmetszete (a szárny szimmetriatengelyében), [1883.] MNL OL T3 - No. 553.

A barokk kori szárny nyugati homlokzatának teljes hosszában a földszinten nyitott (árkádos), az emeleten pedig zárt folyosót építettek, amelyek igen jelentősen javították a rezidencia belső közlekedési kapcsolatait. (A közlekedési hiányosságok hasonló jellegű pótlására történt kísérlet 1866-ban, amikor az emeleti részek elé a már említett vasszerkezetes, függönyfalas, üvegezett folyosót építették, amely folyosó éppen ezen átalakításkor került lebontásra.) A nyugati homlokzat átépítéséról fennmaradt két - egy időpontban készült - archív kép, amelyeken a szerkezetkész, már tető alatt lévő épület látható a még felállványozott középrizalittal. A földszint keleti traktusának, a hátranyúló déli oldalszárnynak, valamint az annak végén lévő kiforduló nyugati szárnynak (a könyvtárszárnynak) az alaprajzi elrendezése szinte semmit nem változott az 1883-87es átépítés során, a legjelentősebb módosulás itt a déli szárny lépcsőházának az átalakítása volt. 


\section{Az épitkezés elókészitése és lebonyolitása}

Festetics (II.) Tasziló mint a hitbizomány várományosa tudatosan készülhetett az örökség átvételére, és kiérlelt koncepciója lehetett a kastély kibővítésére vonatkozóan is, ugyanis nagybátyja 1883. február 5-én bekövetkezett halála után meglehetősen gyorsan peregtek az események, és Rumpelmayer a tervezési megbízása után 1883 augusztusára már terveket készített, majd 1883. október 25-én az építési-kivitelezési lebonyolításra vonatkozó szerződés is megkötésre került Oskar Laske építési vállalkozóval. ${ }^{111}$ (A bécsi lakos Oskar Laske [1841-1911] cseh származású építész, építési vállalkozó volt, aki a prágai Polytechnikum után elvégezte a bécsi Képzőmüvészeti Akadémiát, majd elnyerte az építőmesteri koncessziót, azaz a kivitelezéshez való jogot. Csak kisebb léptékü épületeket tervezett, kivitelezőként főként lakó- és ipari épületek

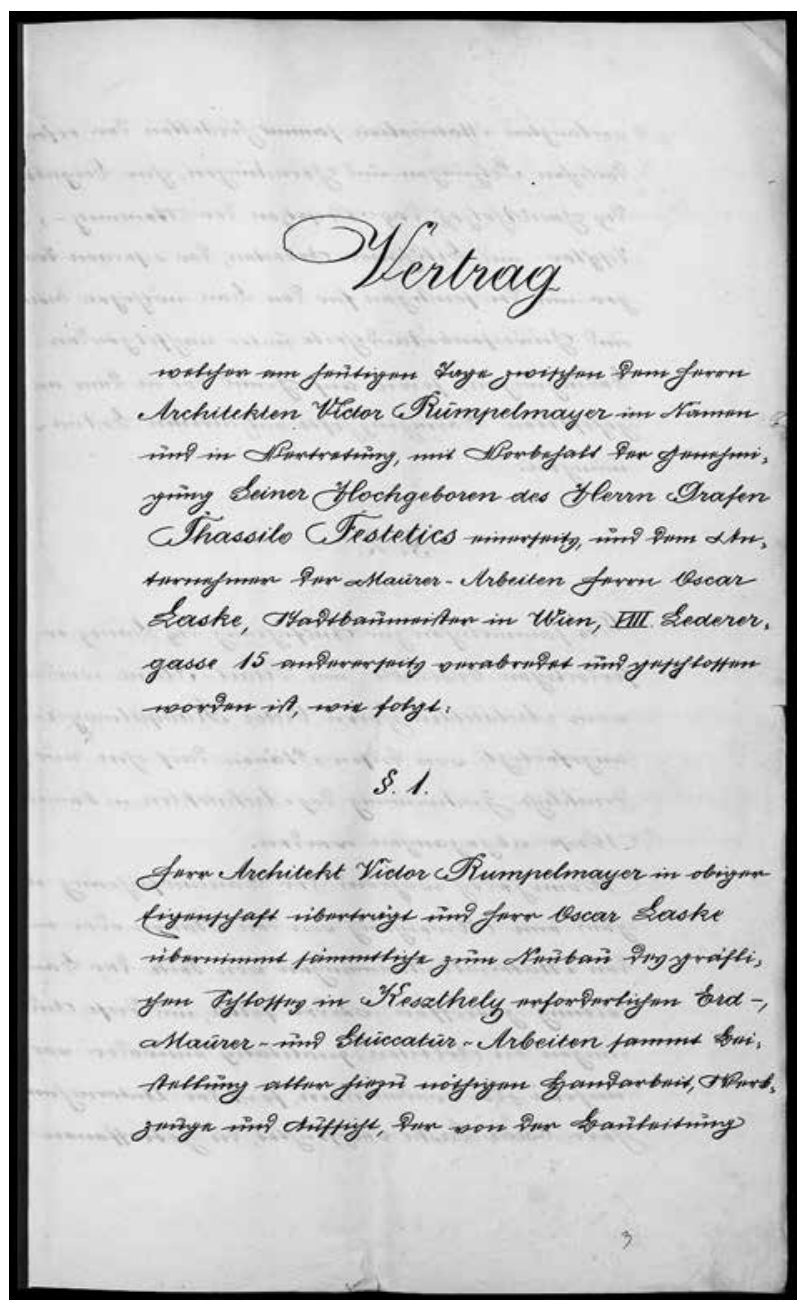

34. Az épitési-kivitelezési lebonyolitásra vonatkozó szerződés elsô oldala [Vertrag über die Baumeister-Arbeiten],

1883. október 25. MNL OL P 274 - 12. t. - a alt. 3 - Nr. 1 (287. doboz, fol. 3.) munkálatait bonyolította, leginkább Bécsben és Alsó-Ausztriában.) ${ }^{112}$ Ezt a szerződést Festetics (II.) Tasziló megbízásából Victor Rumpelmayer kötötte meg, akit a gróf egyúttal a „legfelsőbb építésvezetés" feladatával is megbízott (34-35. kép).

A szerződésben lefektették, hogy az új kastélyrész a már álló épülethez való hozzáépítés legyen, az újonnan emelt épületrész a "galériás" középrészből - végül ide került a torony is -, valamint az újonnan emelt jobb szárnyból - előreugró, nyolcszög alaprajzú tornyokkal - áll. A homlokzati és a részletrajzokat Rumpelmayer maga kellett, hogy elkészítse, és ezektől a kivitelező semmilyen formában nem térhetett el. Ugyanakkor az is kitünik, hogy a tervek az építési-kivitelezési szerződés megkötésének az időpontjára még nem készültek el teljesen, szó esik azon építészi feladatról is, amely szerint egy meglévő, az általános elrendezést mutató kép alapján kellett az egyes terveket elkészíte-

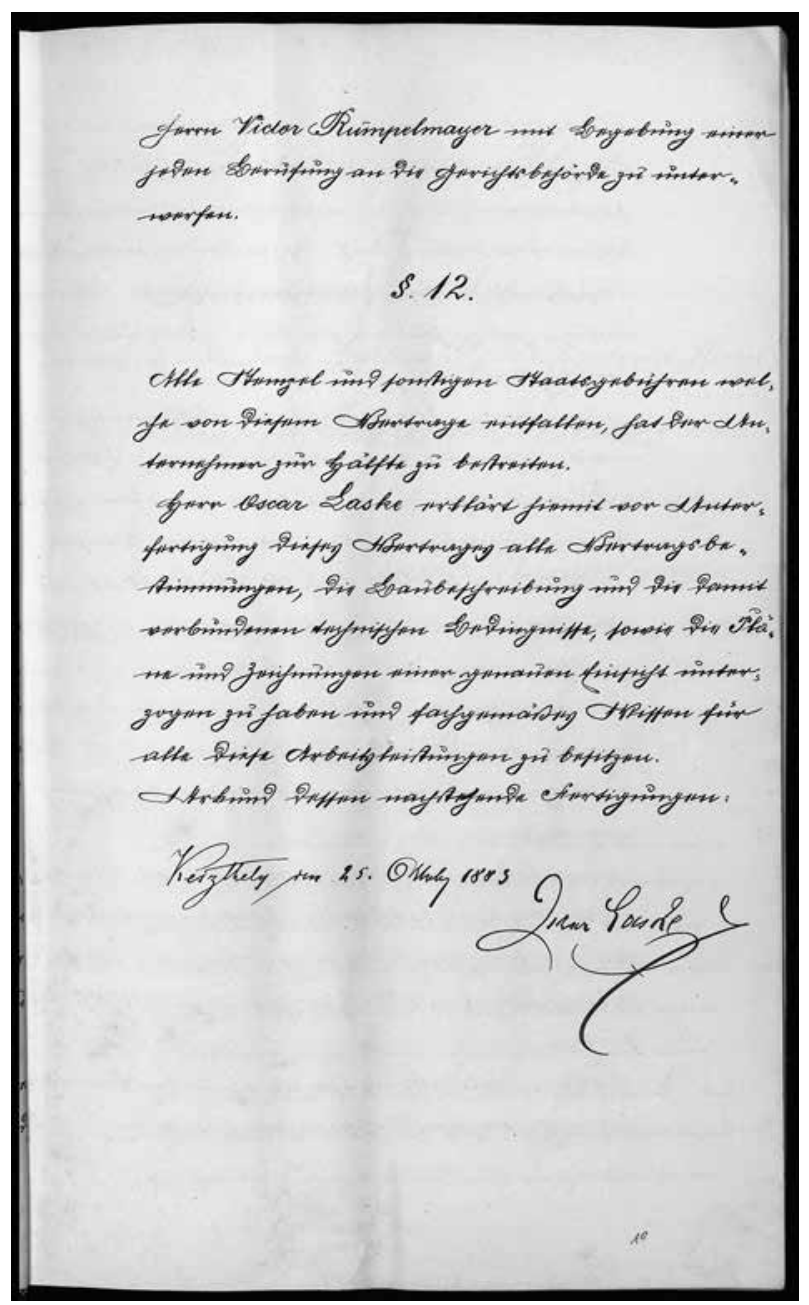

35. Az épitési-kivitelezési lebonyolitásra vonatkozó szerződés utolsó, aláírt oldala [Vertrag über die Baumeister-Arbeiten], 1883. október 25. MNL OL P 274 -12. t. - a alt. 3 - Nr. 1 (287. doboz, fol. 10.) 
ni, ugyanakkor a tervező ettől az előképtől jobbító céllal eltérhetett. A szerződésből kiderül az is, hogy Rumpelmayer tervezte az összes külső és belső díszítőelemet, az ezek elkészítéséhez szükséges sablonokat pedig a kivitelezőnek kellett előállítania és karban tartania.

Oskar Laske a kivitelezési munkák komplett lebonyolítása keretében az elöre elfogadtatott, vagy kipróbálni köteles építési anyagok megrendeléséért és a szakipari munkák kiadásáért, ellenőrzéséért is felelt. Az építési vállalkozónak két évre kellett garanciát vállalnia az épület szilárdságára, és a megállapodás szerint a teljes munkadíj $5 \%$-a csak ezen időszak káresemény nélküli eltelte után került kifizetésre, valamint az is szabályozásra került, hogy a teljes építési időszak időtartamára Laskénak 2000 Gulden értékű kauciót kellett a grófi főkasszában tartania állampapír formájában. A késésért a vállalkozó kötbért volt köteles fizetni, ha pedig hamarabb befejezte (volna) a munkálatokat, akkor a kötbér összegének megfelelő jutalmat kapott (volna). A szerződésben foglaltak szerint vita esetén a gróf és Laske között Rumpelmayer volt a döntőbíró, akinek a döntése ellen nem emelhetett egyik fél sem panaszt, sőt Laske azon jogáról is lemondott, hogy Rumpelmayer ítéletét a gróf és az építész között fennálló szerződéses viszony kapcsán felmerülő összeférhetetlenség miatt ne fogadná el. Rumpelmayer mint építésvezető fel is menthette Laskét abban az esetben, ha a munkások nem lennének elegen, vagy ha nem követnék pontosan a terveket és az építésvezetés utasításait. A szerződésben ez az egy pont van, amely a felmentés szankcióját alkalmazza, az összes többiben Laskénak „,csak” anyagi felelősséget kellett vállalnia. A szerződésből tizenöt oldal nagyrészt a pénzügyi kondíciókat, a felelősségi kérdéseket, és a hibás teljesítés esetén alkalmazandó szankciókat taglalta. Ez utóbbiaknak az elkerülése érdekében készült a függelékben (mellékletben) lévő „elöírásfüzet” (Bedingnis-Heft), amely tizennyolc oldalon keresztül szedte pontokba a minőségi követelményeket. (Szabályozásra került az építés, a felvonulás és a szemétszállítás minden elképzelhető részfolyamata, amelyek befolyásolhatták például az állékonyságot, a nedvesedést, vagy éppen a tüzesetek megelőzését, egy példát említve, pontosan megadták a habarcs keverési arányát is.) Ez a korban is szokatlan részletességű szabályozás a megbízó gróf kérésére történt, és jól tükrözi Festetics kissé akkurátus személyiségét.

A vállalkozási szerződésből kitünik egy pontosabb körülírás és jellemzés nélküli szakmai szervezeti egység létezése is, ez pedig az Építésvezetőség (Bauleitung) volt - amelynek, mint szervezetnek a legfelsőbb vezetését Rumpelmayer látta el -, és amelyről feltételezhető, hogy tulajdonképpen az uradalom építési irodáját és annak egységeit jelentette. Ennek a szervezetnek nyújtotta be a kivitelező a számlát, amely csak a munka minőségének a leellenőrzése után került kifizetésre.

Összességében megállapítható, hogy a negyven oldalas, jogi szempontból igen szigorú, és minden kérdést aprólékosan szabályozó szerződés azt a célt szolgálta, hogy a megrendelő mind költségeit, mind időintervallumát, mind kialakítását, mind pedig minőségét tekintve maradéktalanul azt a végeredményt kapja, amelyet előzetesen elképzelt.

$\mathrm{Az}$ átalakítási és bővítési munkálatok vállalkozási szerződésének nem csak egy aláírt példánya, hanem egy tervezete is fennmaradt. Mindkettőnek, és az igen fontos részüket képező mellékletnek (függeléknek) is ugyanaz a szövege ${ }^{113}$ csak az építési határidők térnek el a két verzióban.

Az 1883. október 25-én aláírt szerződés ütemezése a következőképpen alakult a határidők szempontjából: 1883. december 15-ig kellett elkészülnie a teljes szuterénnek (alagsornak), 1884. július 1-ig a teljes felmenő falazatnak és a tetőszerkezetnek, 1884. december 1-ig a vakolásnak, a kastély teljes átadását pedig 1884. december 30-ra tűzték ki. Anynyi bizonyos, hogy a szerződésben szereplő - rendkívül szűk - véghatáridőre nem készült el a kastély, sőt már az első részteljesítési időpontokhoz képest is komoly csúszás keletkezett.

Természetesen súlyos problémát vetett fel az is, hogy 1885. június 14-én ötvenöt éves korában váratlanul elhunyt Victor Rumpelmayer. Ekkor a munkálatok irányítását Gustav Haas és Maximilian Paschkis bécsi múépítészek, építési vállalkozók vették át, az ellenőrzés, a revízió feladatköre pedig egy bécsi ügyvédhez, dr. Korper Károlyhoz került. ${ }^{114}$

$\mathrm{Az}$ épület Rumpelmayer halálakor már tető alatt állt, így az építkezés befejezése is lényegét tekintve az ő tervei és elképzelései alapján valósult meg. ${ }^{115}$ A kastélyépítési munkálatok 1887-ben zárultak le, a Keszthely című újság azon év október 23-án így írt az eseményről: „Festetics Tassilo gróf ur helybeli pompás palotája teljesen elkészülvén, az épitészektől a mult napokban vétetett át a minden izében sikerült nagyszerü monumentális épület, mely alkalommal - mint halljuk - az épitészek a palota aranykulcsát nyujtották át a tulajdonos grófnak." ${ }^{116}$ A parképítési és egyéb munkálatok azonban tovább folytatódtak, egészen 1890-ig. Az építkezés a levéltárban őrzött „A keszthelyi grófi palota építési költsége az építés kezdetétől 1889. jan. 1-ig pótlólag 1889. júl. 1-ig 1890. dec. 31-ig" címú kimutatás bontása szerint első ütemben 1318198 forintba került, majd pótlólag további 2623 forintot, végül 1890. december 31-ig további 234472 forintot 


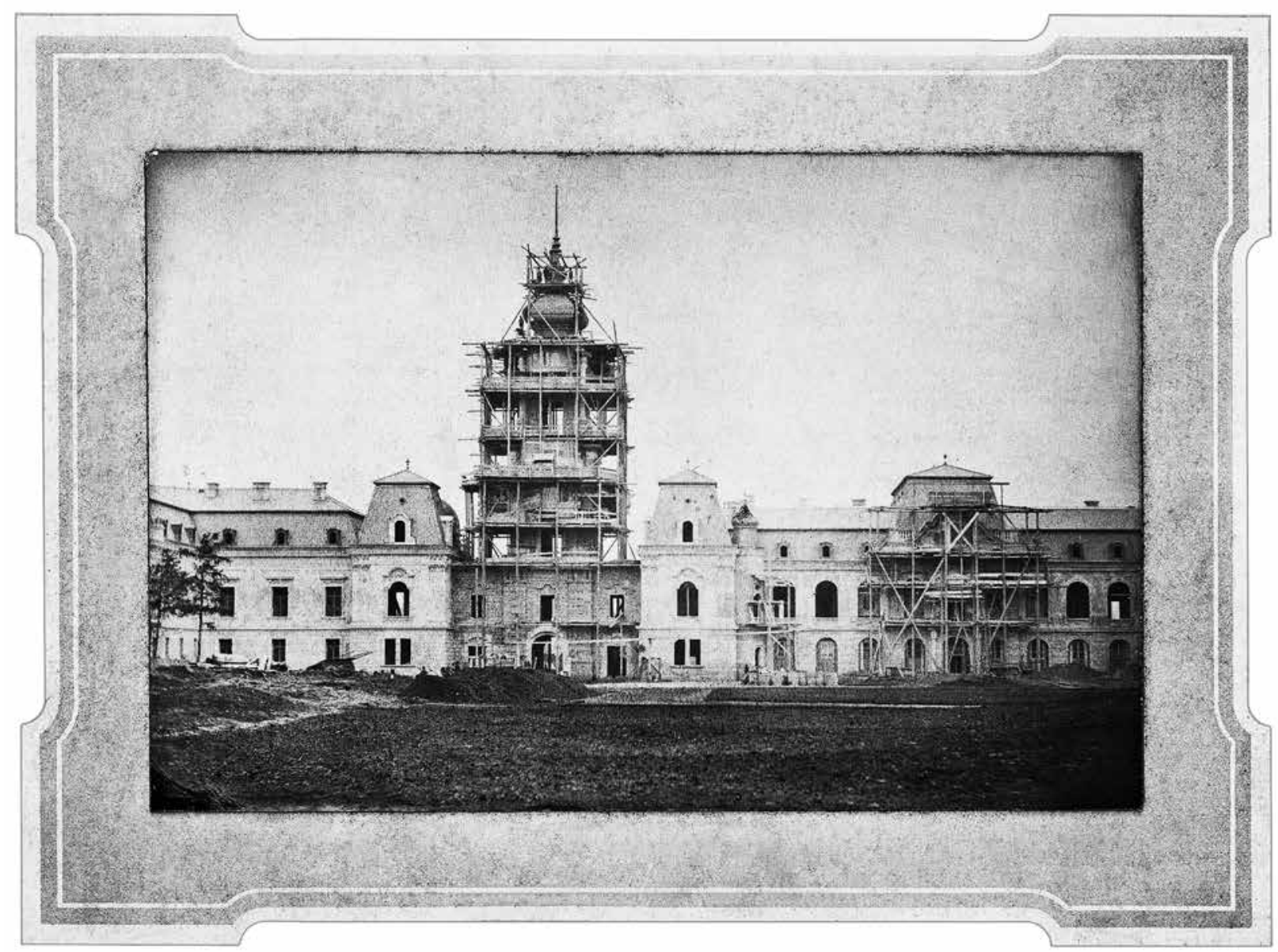

36. A nyugati homlokzat átépítéséról fennmaradt archív kép, 1885 körül. MNL OL P 240 - 1. t. - j alt. - No. 40.

fizettek ki, valamint 18490 forint értékben felhasználtak 3400644 darab - az uradalomban égetett téglát is. ${ }^{117}$ Amennyiben az összesítés minden tételt tartalmaz, akkor ez mindösszesen 1573783 forintot tett ki. A Vasárnapi Ujság 1893-as tudósítása szerint több mint kétmillió forintba kerültek a munkálatok. ${ }^{118} \mathrm{Az} 1887$ és 1890 között keletkezett elszámolásokon a kastély Építésvezetőségének a pecsétje, valamint az azt vezető "Max" Paschkis és Gustav Haas aláírása látható (36-37. kép).

\section{Az átépitett kastély kialakitása, szakipari munkái}

$\mathrm{Az}$ átalakítás során a keleti homlokzaton a középrizalit timpanonját baluszteres attikára és egy tengely szélességü címeres oromzatra cserélték, a középrizalit előtt új, nagyobb méretű erkélyt is létesítettek. A nyugati homlokzat középrizalitján az órával ellátott timpanont lendületes, tört ívű oromzatba foglalt címer váltotta fel. Mint már említésre került, a kastély historizáló, neobarokk és neorokokó külső és belső dekorációjához Rumpelmayer készített rajzokat mind az új, mind a régi szárny esetében, utóbbi külső díszítményei is legnagyobbrészt ekkor készültek. (Az egyik tervlapon látható egy olyan változat is, amely az új, historizáló északi szárny mellett még a régi, klasszicizáló késő barokk formájában tünteti fel a déli szárnyat.) Dúsabb, „barokkosabb" lett az épületplasztika, az újraformált szemöldökpárkányok alatt naturalisztikus állatés emberfejeket, valamint trófeák dombormúveit helyezték el. A homlokzatok ablakait erőteljesebb pilaszterekkel tagolták, a déli szárny kiforduló nyugati szárnya (a könyvtárszárny) pedig mind a keleti homlokzat bal szélén, mind a nyugati homlokzat bal és jobb szélén új rizalitokat kapott, amelyek előtt oszlopokon nyugvó erkélyeket is kialakítottak. A kastély egészét új manzárdtetőzettel látták el, korábban (1866 után) csak a barokk kori szárny keleti homlokzatának középrizalitja, két sarokrizalitja és nyugati homlokzatának bal oldali rizalitja volt manzárdtetős kialakítású, de ekkor ezekre is új, magasabb manzárdtetőt húztak. A manzárdtetőben tetőablakokkal megvilágított emeletet alakítottak ki 


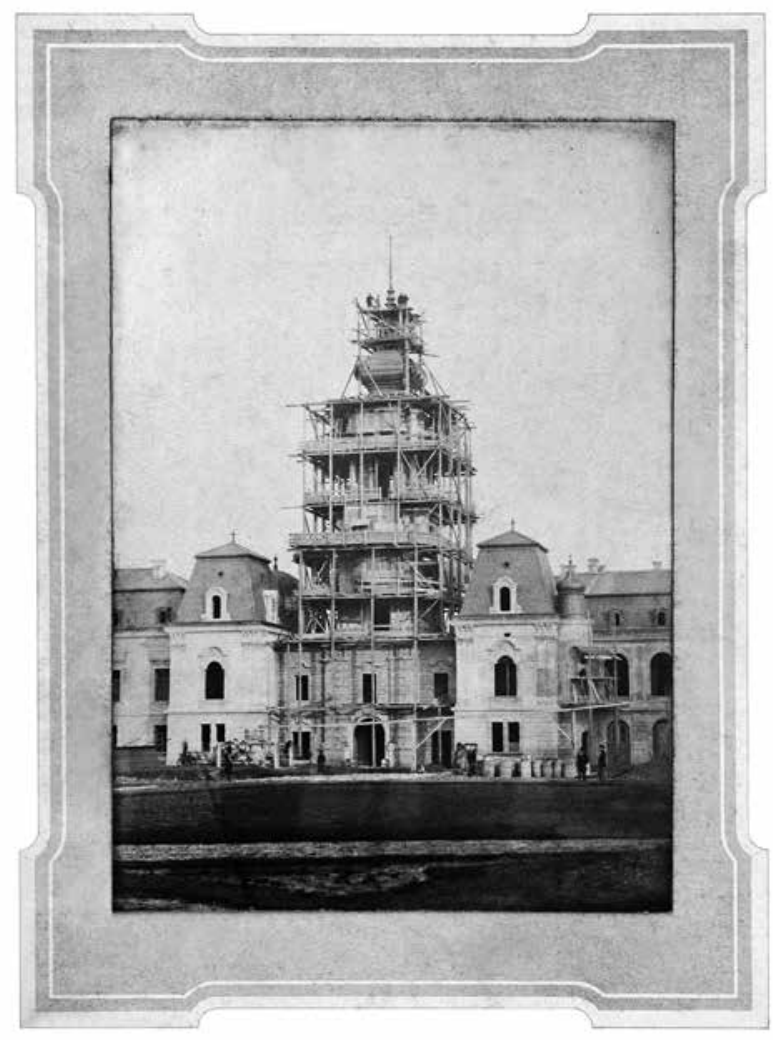

37. A nyugati homlokzat átépitéséról fennmaradt archív kép, 1885 körül. MNL OL P 240 - 1. t. - jalt. - No. 33.

szobákkal. A keszthelyi kastély új tornyának a mintája a drezdai Zwinger koronakapujának hagymasisakja lehetett - még a növényi díszítés is átvételre került -, míg az új, északi szárny nyolcszögü tornyai a bécsi Felső-Belvedere saroktornyaira hasonlítanak.

A szakipari munkákat főként osztrák cégek és iparosok végezték, helyi mesterek és iparosok kisebb megbízásokat kaptak. A festési munkákat a bécsi Chr. Jürs, az üvegesmunkákat Jos. Rantl W.\&S., a bádogozási munkákat a bécsi Karl Wiernsee, a lakatosmunkákat Ludwig Wilhelm, a csatornázási munkákat pedig a bécsi John Thomas Grumlick cégek végezték, az ajtókat, az ablakokat és a padlót pedig a Thüren-, Fenster-, \&Fußboden FabriksGesellschaft nevü cég szállította. ${ }^{119}$

A kapuk mindenütt új, neobarokk kovácsoltvas szárnyakat kaptak, ezeket Marton Lajos pozsonyi mülakatos készítette 1885 és 1887 között Haas és Paschkis rajzai alapján. A kastélyparkban elhelyezett öntött- és kovácsoltvas kandelábereket, valamint az erkélyrácsokat és a két díszlépcső - az ún. márványlépcső és az ekkor épült északi lépcsőház új lépcsőrácsait Biró Antal bécsi múlakatos készítette 1887-ben. A barokk kori szárny ún. márványlépcsőházát - mint már említésre került - kibővítették

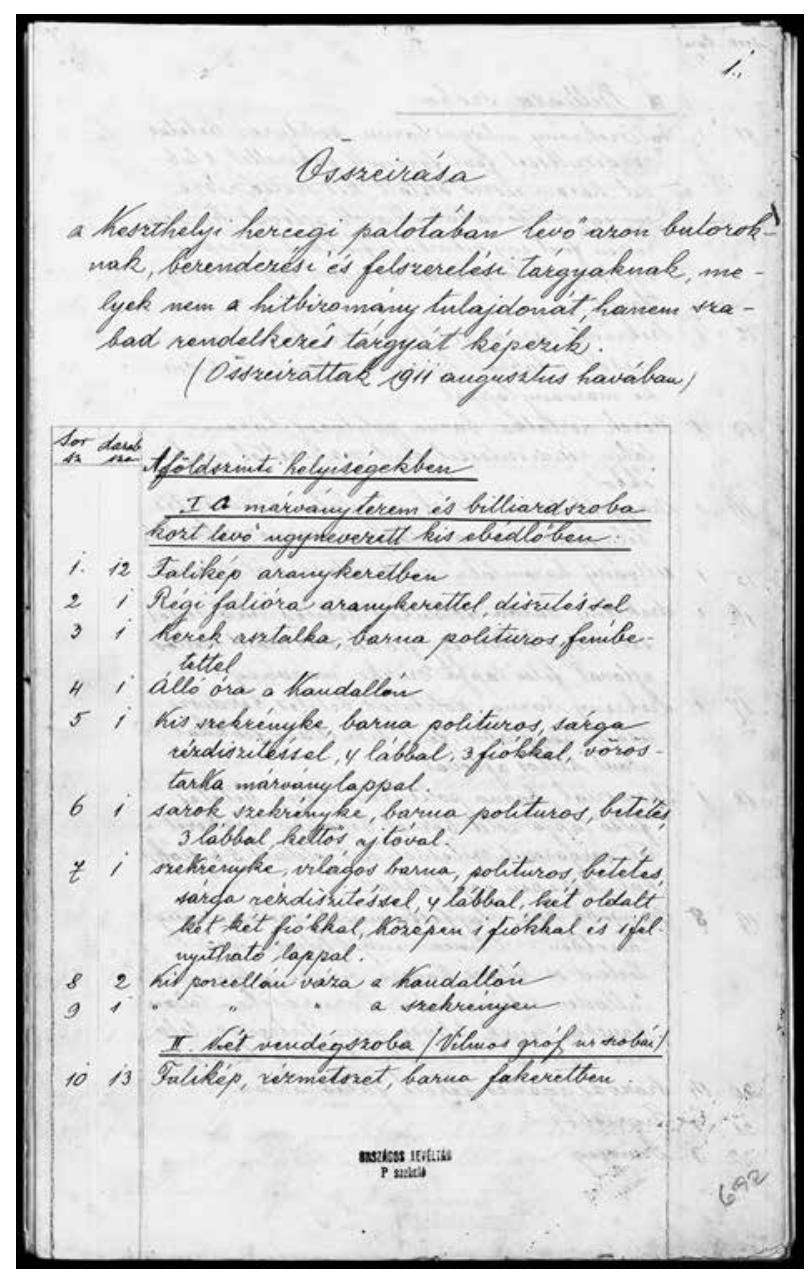

38. Az 1911-es leltár első oldala. MNL OL P 236 - IX. t. 1911 alt. - Nr. 1 (94. nagydoboz, fol. 692.)

és átalakították, Köck Antal kőfaragó készített bele új lépcsőt carrarai márványból. ${ }^{120}$

A további közreműködők Péczely Piroska tanulmányaiban már említésre kerültek. Az új rezidenciában az 1911-es leltár tanúsága szerint 114 helyiség sorakozott. ${ }^{121}$ A belső kialakítást, valamint a lakosztályok és a kiemelt terek berendezését a bécsi Portois és Fix szakcég végezte, amely sok különböző stílusú régi bútort szállított a keszthelyi kastély számára. Az új északi épületszárnyban az emeleten a vendégfogadás reprezentatív díszterei kaptak helyet, a kiforduló nyugati szárnyban mind a földszinten, mind az emeleten több helyiségből álló vendéglakosztályokat alakítottak ki, amelynek XV. Lajos stílusú (rokokó) teljes berendezését is a Portois és Fix végezte. Az alagsorban pedig a konyha és a műhelyek sorakoztak. ${ }^{122} \mathrm{Az}$ új, historizáló szárny vendégfogadó terei közül a velencei tükörterem falait Boulle stílusában rézzel berakott és faragott faburkolatokkal díszítették. Ezen terem után a nagy és a kis bálterem következett, amelyeknek 
a falain és mennyezetén hangszeres emblémákkal és puttókkal díszített neorokokó stukkódísz látható (38. kép).

Az északi oldalszárny és kiforduló nyugati szárnya által L alakban közrefogott területen egy az alagsorral egy járószinten lévő mélyebb udvar is létesült, amelynek főként gazdasági funkciója volt, és amelyet külön kapun keresztül lehetett megközelíteni.

A keszthelyi kastély építészeti kialakítása ezen átépítést követően már nem változott jelentősen az épület 1948-as államosításáig.

\section{JEGYZETEK}

1 Péczely Piroska: A keszthelyi Festetics kastély és belső berendezése. Múzeumok Központi Propaganda Irodája, Budapest 1958; Péczely Piroska: A keszthelyi Festeticskastély (Müemlékeink). Budapest 1964; Péczely Piroska: A keszthelyi Festetics-kastély. Pannonia, Budapest 1968.

2 A jelen tanulmány tömörített, az új eredményeket kiemelő és tudományos apparátussal ellátott változata a következő publikációnak: Virág Zsolt - Németh Nóra: A keszthelyi Festetics-kastély története. In: Virág Zsolt szerk.: Keszthelyi Festetics-kastély - Helikon Kastélymúzeum. Várkastély Kiadó, Keszthely 2015, 32-89.

3 Magyar Nemzeti Levéltár (MNL) Országos Levéltár (OL Budapest), P 235, Gersei Pethő család levéltára, Comitatus Zaladiensis, No. 805.

4 MNL OL P 235 Gersei Pethő család levéltára Comitatus Zaladiensis - No. 865

5 MNL OL P 235 Gersei Pethő család levéltára Comitatus Zaladiensis - No. 899.

6 MNL OL P 235 Gersei Pethő család levéltára Comitatus Zaladiensis - No. 1076.

7 Valamennyi, a tulajdonjogot igazoló és biztosító oklevéllel együtt. MNL OL P 235 Gersei Pethő család levéltára - Comitatus Zaladiensis - No. 1130.

8 MNL OL P 235 Gersei Pethő család levéltára Comitatus Zaladiensis - No. 1156a.

9 Csomortány Levente - Gömöry Judit - Rozman Viktor: A keszthelyi Festetics-kastély jelenlegi helyreállítással érintett területeinek falfelületein végzendő roncsolásos falszövetvizsgálat müemléki tudományos dokumentációja. Előzetes jelentés. (Kézirat, 2013.)

10 „Vagyon Keszthelyen az Polgárvároson egy testimoniális ház, mely major ház volt és Bakó Farkas uramtul váltatott ki a szent egyház ellenében, napnyugati út melynek is épületi és circumstentiai e képpen találtatnak: ..." Urbarialis Conscriptio Bonorum... MNL OL P 276 Központi birtokigazgatás és gazdálkodások I - 1 - a. - 1688-1749 (1. doboz, fol. 8-18v)

11 Tóth Sándor: A keszthelyi Balatoni Múzeum középkori kőtára. In: Zalai Múzeum 2. Zalaegerszeg 1990, 153.

12 Tóth i. m. (11. j.) 161.

13 Csomortány-Gömöry-Rozman i. m. (9. j.)

14 Péczely i. m. 1968 (1. j.) 31.

15 MNL OL P 274 Birtokigazgatással kapcsolatos iratok - II. - 7. j. - 3 - Nr. 2/73. Idézi: Tóth i. m. (11. j.) 153.

16 Tóth i. m. (11. j.) 161

17 MNL OL T 3 - Nr. 4

18 MNL OL T 3 - Nr. 5

19 MNL OL T 3 - Nr. 20.

20 MNL OL T 3 - Nr. 31.

21 MNL OL T 3 - Nr. 40.

22 MNL OL T 3 - Nr. 276.
23 Bél Mátyás: Zala vármegye leírása. (Fordította: Szabó Béla.) In: Káli Csaba szerk.: Zala vármegye a XVIIIXIX. században két korabeli leírás alapján. In: Zalai Gyüjtemény 46. Zalaegerszeg 1999, 44-45.

24 MNL OL T 3 - Nr. 4.

25 MNL OL P 276 Központi birtokigazgatás és gazdálkodások - I - 1 - a. - 1688-1749 az uradalom egészére vonatkozó számadások 1749, Pénzbeli kifizetések (1. doboz, fol. 564v). Idézi: Tóth i. m. (11. j.) 161.

26 Koppány Tibor: A Balaton környékének müemlékei. (Művészettörténet-Müemlékvédelem, 3.) Budapest 1996, 50.

27 MNL OL T 3 - Nr. 5.

28 MNL OL T 3 - Nr. 20.

29 MNL OL T 3 - Nr. 31.

30 MNL OL T 3 - Nr. 40.

31 Keszthely, Balatoni Múzeum Térképtára, ltsz.: 75.525 .

32 MNL OL T 3 - Nr. 32.

33 „Ansicht oder aufriss [Aufriss] der Kastellen, welches die gnädige Herrschaft gesinetin Kästhell Erbauen zu lassen" MNL OLOL T 3 - Nr. 32.

34 MNL OL P 240 - 1. tétel - a. altétel - Nr. 488.

35 MNL OL T 3 - Nr. 554

36 MNL OL T 3 - Nr. 122 és 291.

37 Szabó Dezső: A herceg Festetics-család története. Budapest 1928, 171-172.

38 MNL OL T 3 - Nr. 284; Országos Széchényi Könyvtár (OSzK), Térképtár TK 520 és OSzK TK 702.

39 MNL OL T 3 - Nr. 334

40 Kurucz György: Keszthely grófja. Festetics György. Budapest 2013, 265-266. és MTA BTK Müvészettörténeti Intézet Levéltári Regeszta-gyüjteménye, A-I-47. Az Országos Levéltárban őrzött iratokról készült regeszták, a Festetics család iratai. 0022 cédula (OMF-Rozgonyi): „Inventar über... Keszthelyer Kastelln zu Ende October Anni 1782. Gut und brauchbare gefundene Mobilien". MNL OL P 236 - 9. tétel - 1782 altétel (91. nagydoboz, fol. 506-577.)

41 „Inventar über... Keszthelyer Kastelln zu Ende October Anni 1782. Gut und brauchbare gefundene Mobilien". fol. 507. MNL OL P 236 - 9. tétel - 1782 altétel. (91. nagydoboz, fol. 506-577.)

42 Kurucz i. m. (40. j.) 109.

43 „Inventar über... Keszthelyer Kastelln zu Ende October Anni 1782. Gut und brauchbare gefundene Mobilien". MNL OL P 236 - 9. tétel - 1782 altétel (91. nagydoboz, fol. 506-577.)

$44 \mathrm{Az}$ alaprajzot először publikáló Péczely Piroska is megjegyezte, hogy „Erre az építkezésre okmányszerű adatok nincsenek, de mivel a ma is meglevő homlokzati rész és déli szárny beosztása még apró részleteiben is 
egyezik a tervrajzzal, hihető, hogy az valóságos állapotot rögzít le." Péczely i. m. 1968 (1. j.) 22.

45 MNL OL T 3 - Nr. 334.

46 „A Festetics Kastély 1812-ben.” Keszthely, Helikon

Kastélymúzeum, C 2929, 24. sz. köteg.

$47 \mathrm{Az}$ alaprajzot először publikáló Péczely Piroska is megjegyezte, hogy „[e]rre az építkezésre okmányszerü adatok nincsenek, de mivel a ma is meglevő homlokzati rész és déli szárny beosztása még apró részleteiben is egyezik a tervrajzzal, hihető, hogy az valóságos állapotot rögzít le." Péczely i. m. 1968 (1. j.) 22.

48 „Personalis status tabella, keszthelyi uradalom az 1796-os évre" MNL OL P 279 - 1795. év - Nr. 122.; Koppány i. m. (26. j.) 59.

49 Koppány i. m. (26. j.) 59.

50 „Grundriß des Keszthelyer Schloßes im ietzigen Stande 1812" MNL OL T 3 - Nr. 332-333.

51 MNL OL S 78 - 312. téka - 32. szelvény (1858.)

52 MNL OL T 3 - Nr. 554.

53 MNL OL P 274.

54 Péczely i. m. 1958 (1. j.) 25.

55 MNL OL P 279 - 2. sorozat ülésjegyzők - 242. kötet (1743) no. 10.

56 MNL OL P 279 - 2. sorozat ülésjegyzők - 243. kötet (1794) no. 202.

57 MNL OL P 279 - 2. sorozat ülésjegyzők - 243. kötet (1794) no. 300.

58 MNL OL P 279 - 2. sorozat ülésjegyzők - 243. kötet (1794) no. 1097./3.

59 MNL OL P 279 - 2. sorozat ülésjegyzők - 245. kötet (1795-96) no. 113.

60 MNL OL P 279 - 2. sorozat ülésjegyzők - 245. kötet (1795-96) no. 590. Fügerről legújabban: Saur Allgemeines Künstlerlexikon XLVI. München-Leipzig 2005, 87-90. [Keszthely nincs említve.]

61 MNL OL P 279 - 2. sorozat - ülésjegyzők - 245. kötet (1795-96) no. 590. Prokoppról 1. Pusztai László in: Szabolcsi Hedvig - Galavics Géza szerk.: Művészet Magyarországon 1780-1830. Kiállításkatalógus, MTA-MNG Budapest 1980, 294-297. [Keszthely nincs említve.]

62 MNL OL P 279 - 2. sorozat ülésjegyzők - 245. kötet (1795-96) no. 692.

63 MNL OL P 279 - 2. sorozat ülésjegyzők - 245. kötet (1795-96) no. 887. Csak a feljegyzés maradt meg róla, az összeg nem. Szó szerint: „Fischer Márton bécsi képfaragás tudománybeli professzor úr megküldi Sebestyén úrnak a nála találatos képeknek taxája és nagysága specificátióját, mely is az protocollumhoz tétetik." Fischerről legújabban: Saur Allgemeines Künstlerlexikon XL. München-Leipzig 2004, 365. [Keszthely nincs említve, ebből az időszakból főleg osztrák művek.]

64 MNL OL P 279 - 2. sorozat ülésjegyzők - 245. kötet (1795-96) no. 613.

65 MNL OL P 279 - 2. sorozat ülésjegyzők - 246. kötet (1797) no. 242.

66 MNL OL P 279 - 2. sorozat ülésjegyzők - 246. kötet (1797) no. 767.

67 MNL OL P 279 - 2. sorozat ülésjegyzők - 246. kötet (1797) no. 1124.

68 MNL OL P 279 - 2. sorozat ülésjegyzők - 246. kötet (1797) no. 767.

69 MNL OL P 279 - 2. sorozat ülésjegyzők - 247. kötet (1798) no. 338.
70 MNL OL P 279 - 2. sorozat ülésjegyzők - 247. kötet (1798) no. 1144.

71 MNL OL P 279 - 2. sorozat ülésjegyzők - 247. kötet (1798) no. 1296.

72 MNL OL P 279 - 2. sorozat ülésjegyzők - 247. kötet (1798) no. 1034.

73 MNL OL P 279 - 2. sorozat ülésjegyzők - 249. kötet (1799) no. 1231., 1332.

74 Péczely i. m. 1958 (1. j.) 36.

75 MNL OL P 279 - 2. sorozat ülésjegyzők - 249. kötet (1799) no. 20.

76 MNL OL P 279 - 2. sorozat ülésjegyzők - 249. kötet (1799) no. 505.

77 Kurucz i. m. (40. j.) 264.

78 MNL OL P 279 - 2. sorozat ülésjegyzők - 247. kötet (1798) no. 250/5., 573. Idézi: Péczely i. m. 1958 (1. j.) 26. Vö. Saur Allgemeines Künstlerlexikon XL. München-Leipzig 2004, 307.

79 MNL OL P 279 - 2. sorozat ülésjegyzők - 247. kötet (1798) no. 1361. Idézi: Péczely i. m. 1958 (1. j.) 26.

80 MNL OL T 3 - Nr. 273-277.

81 Velladics Márta - Virág Zsolt: A gyulai HarruckernWenckheim-Almásy-kastély története. In: Virág Zsolt szerk.: Gyulai Almásy-kastély Látogatóközpont. Gyula 2015, 33, 35.

82 MNL OL P 274 Tiszttartóság 1799. júl. 30. Idézi: Kállay István: A magyarországi nagybirtok kormányzata 1711-1848. (Magyar Országos Levéltár kiadványai, III. Hatóság- és hivataltörténet, 5.) Budapest 1980, 130.

83 MNL OL T 3 - Nr. 277.

84 MNL OL T 3 - Nr. 332-333.

85 Beschreibung von Keßthely. In: Zeitschrift von und für Ungarn: zur Beförderung der vaterländischen Geschichte, Erdkunde und Literatur, 1. kötet. 1802, 186-189.

86 Birkás Géza: Francia utazók Magyarországon. In: Acta Universitatis Szegediensis sectio Philologica, tomus XVI. series nova T. II. Szeged 1948, 113.

87 Richard Bright: Travels from Vienna Through Lower Hungary. Archibald Constable\& Co., Edinburgh 1818. 88 ,Inventiert und gezeichnet F. Ladislaus 1811” MNL OL T 3 - Nr. 622.

89 Bibó István: A magyar építészeti szakirodalom kezdetei. In: Zádor Anna - Szabolcsi Hedvig szerk.: Művészet és felvilágosodás. Müvészettörténeti tanulmányok. Budapest 1978, 101-102.

90 MNL OL S 68, No. 192. Felirata: „Ein Theil der Keszthelyer Schloss-Bau-Anlage".

91 „Mappa fundorum intra villanorum oppidi Keszthely ad illustrisimum dominum comitem Ladislaum Festetits de Tolna" OSzK TK, 1305.

92 OSzK Kisnyomtatványtár Metszet 45e/505

93 MNL OL S 78 - 312. téka - 32. szelvény, 1858.

94 ,in dem kleinen Kastell Gebäude ins Schloßes zu Keszthely" MNL OL P 274 - 12. tétel - a altétel (289 doboz, fol. 631-764).

95 MNL OL P 274 központi birtokigazgatás és gazdálkodás birtokigazgatással kapcsolatos iratok (289 doboz, fol. 747) Csesznák László elnök, Lukács János mb. felügyelő, Eberhardt József számvevő, Wolf Frigyes titoknok levele (I.) Taszilónak, Keszthely, 1866. dec. 6.

96 MNL OL T 3 - Nr. 554.

97 Sisa József: Kastélyépítészet és kastélykultúra Magyarországon. A historizmus kora. Budapest 2007, 185-186, 304. 
98 MNL OL P 236 - 1. tétel - 11. altétel - No. 146. Friedrich Flohr levele Festetics (II.) Györgyné Erdődy Eugéniának, Bécs, 1859. jún. 4.

99 „A keszthelyi grófi kastélyról Metzl Kamill akkori grófi szakács által 1871. évben készített ceruzarajzról Timár Rózsi fényképész által 1942. nov. hóban készített fénykép. Kelet felé néző utcai front." Keszthely, Helikon Kastélymúzeum, C 2907, 53. sz. köteg.

100 Keszthely, Helikon Kastélymúzeum, C 2907, 53. sz. köteg.

101 „Keszthelyi urasági kastélyban lévő házi butor és külömbféle eszköz leltár 1862/63 186/6 és 186/6 h évekre." MNL OL P 236 - 9. tétel - 1867 altétel - No. 1. (98. kötet, fol. 378-394.)

102 MNL OL P 235 Gersei Pethő család leltára - 13. tétel - Majoratus No. 432., 433. idézi: Szabó i. m. 355., 387. (37. j.)

103 MNL OL P 252 - 7. tétel (2. nagydoboz, kihirdetett másolat 3 példányban fol. 131-139.), pótvégrendelet (2. nagydoboz fol. 141-145)

104 Sisa i. m. 2007 (97. j.) 272-273.

105 Uo. 308.

106 Victor Rumpelmayer, Architektenlexikon, Wien 1770-1945. Elérhető online az Architekturzentrum, Wien honlapjáról: architektenlexikon.at/de/1236.htm (utoljára letöltve: 2016. 03. 29.)

107 MNL OL T 3 - Nr. 544-553; szignálatlan: Nr. 544.

108 MNL OL T 3 - Nr. 546, 548, 553.

109 Budapest, Forster Központ, Tervtár 4025, 8410.

110 MNL OL T 3 - Nr. 277.

111 „Vertrag über die Baumeister-Arbeiten“ MNL OL P 274 Központi birtokigazgatás és gazdálkodás - XII. Építkezések - a., a Keszthelyi kastély építkezései. (287. doboz, fol. 3-10.)
112 Oskar Laske, Architektenlexikon, Wien 17701945. Elérhető online az Architekturzentrum, Wien honlapjáról: architektenlexikon.at/de/351.htm (utoljára letöltve: 2016. 03. 29.)

113 ,Vertrag über die Baumeister-Arbeiten" MNL OL P 274 Központi birtokigazgatás és gazdálkodás XII. Építkezések - a., a Keszthelyi kastély építkezései (287. doboz fol. 3-10.); „Bedingnisheft der BaumeisterArbeiten” (uo. fol. 11-14.). Aláíratlan verzió: „Vertrag über die Baumeister-Arbeiten (uo. 288. doboz 229-236.) $f$. Bedingnisheft der Baumeister-Arbeiten. (uo. fol. 237-246.)

114 „A keszthelyi grófi palota építési költsége az építés kezdetétől 1889. jan. 1-ig, pótlólag 1889. júl. 1-ig 1890. dec. 31-ig." MNL OL P 274 központi birtokigazgatás és gazdálkodás birtokigazgatással kapcsolatos iratok - XII. tétel - a altétel építkezési iratok. (286. doboz fol. $249 \mathrm{v}-251$.)

115 Péczely i. m. 1968 (1. j.) 25.

116 [Rövid hír] Keszthely, 1887. október 23. 2.

117 „A keszthelyi grófi palota építési költsége az építés kezdetétől 1889. jan. 1-ig, pótlólag 1889. júl. 1-ig 1890. dec. 31-ig." MNL OL P 274 központi birtokigazgatás és gazdálkodás birtokigazgatással kapcsolatos iratok - XII. tétel - a altétel építkezési iratok. (286. doboz fol. 249v-251.)

118 A keszthelyi kastély. Vasárnapi Ujság XL. évf. 1893, 42. szám, 702.

119 MNL OL P 274 - XII. tétel - a (287. doboz)

120 Péczely i. m. 1958 (1. j.) 57.

121 „A keszthelyi hercegi kastélyban lévő azon bútorok és felszerelési tárgyak összeírása, melyek nem hitbizományiak, hanem szabad rendelkezés tárgyát képezik, felvéve 1911. aug." MNL OL P 236 - 9. tétel - 1911 altétel - Nr. 1. (94. nagydoboz, fol. 692-703.)

122 Sisa i. m. 2007 (97. j.) 209.

\section{CONSTRUCTION HISTORY OF THE FESTETICS PALACE OF KESZTHELY IN THE LIGHT OF NEW RESEARCH}

As recent researches in archives, map libraries and the physical building have revealed, the Festetics palace of Keszthely was built in three main periods, and between the second and the third phases a major reconstruction can also be identified. The approximately rectangular eastern main wing was built during the proprietorship of Kristóf Festetics in 1745 and 1750 in baroque style. It is not yet known who designed this phase of construction, but the finishing touches were done with manorial master builder Kristóf Hoffstedter playing an important role. Though the surviving plans suggest that on several occasions the idea of extending the building to a U shape was considered, an asymmetrical L-shaped southern wing was eventually built during Count György (I) Festetics between 1792 and 1804 with its outward-turning section as the library wing. The neo-classical late baroque style addition was based on the logic of Kristóf Hoffstedter's earlier plans. In 1866 Tasziló (I) Festetics had the residence modified in historicist style, after plans most probably made by the Viennese architect Friedrich Flohr who also supervised the construction. The current form of the palace emerged during the proprietorship of Count (later Prince) Tasziló (II) Festetics in 1883-87 under the aegis of historicism, in revived baroque and rococo styles.
That was when the northern L-shaped wing was added, to complete one of the largest aristocratic Hungarian mansions. The plans of reconstruction and extension were made by the Viennese architect Victor Rumpelmayer under the guidance of the owner. Nine plan drawings in ink survive in the archive. After the death of the architect in 1885 construction went on under the supervision of Viennese architects and building contractors Gustav Haas and Maximilian Paschkis. The building contractor was the firm of Oskar Laske. For the interior design and the decoration of the suites and central spaces the Viennese Portois and Fix company was contracted.

VIRÁG Zsolt művészettörténész / art historian, Magyar Kastélyprogram Nonprofit Kft. virag.zsolt@kastelyprogramkft.hu

NÉMETH Nóra művészettörténész / art historian, naemeth nora@mailbox.hu

Kulcsszavak: kastély, barokk, historizmus, Keszthely, Festetics család, Hoffstedter Kristóf, Victor Rumpelmayer, Portois és Fix (Bécs) / Keywords: castle, baroque, historicism, Keszthely, Festetics family, Kristóf Hoffstedter, Victor Rumpelmayer, Portois \& Fix (Vienna) 